University of Arkansas, Fayetteville

ScholarWorks@UARK

Graduate Theses and Dissertations

$12-2014$

\title{
Incarcerating Exceptional Pupils: Is there a School-to-Prison Pipeline in Eastern Oklahoma?
}

\author{
Brett Alan Fitzgerald \\ University of Arkansas, Fayetteville
}

Follow this and additional works at: https://scholarworks.uark.edu/etd

Part of the Criminology Commons, Education Policy Commons, and the Special Education and Teaching Commons

Citation

Fitzgerald, B. A. (2014). Incarcerating Exceptional Pupils: Is there a School-to-Prison Pipeline in Eastern Oklahoma?. Graduate Theses and Dissertations Retrieved from https://scholarworks.uark.edu/etd/2105

This Dissertation is brought to you for free and open access by ScholarWorks@UARK. It has been accepted for inclusion in Graduate Theses and Dissertations by an authorized administrator of ScholarWorks@UARK. For more information, please contact scholar@uark.edu. 
Incarcerating Exceptional Pupils: Is There a School-to-Prison Pipeline in Eastern Oklahoma? 
Incarcerating Exceptional Pupils: Is There a School-to-Prison Pipeline in Eastern Oklahoma?

A dissertation submitted in partial fulfillment

of the requirements for the degree of

Doctor of Philosophy in Public Policy

by

\author{
Brett A. Fitzgerald \\ Northeastern State University \\ Bachelor of Arts in Speech and Criminal Justice, 1985 \\ Master of Science in Criminal Justice Administration, 2006
}

December 2014

University of Arkansas

This dissertation is approved for recommendation to the Graduate Council.

Dr. Brinck Kerr, III

Dissertation Director

Dr. Valerie H. Hunt

Committee Member
Dr. Patricia R. Koski

Committee Member 


\begin{abstract}
The school-to-prison pipeline metaphor represents an educational environment that allows public schools to push many at-risk children out of school and into the juvenile justice system or even worse, the adult criminal justice system (Wald and Losen, 2003; Lynn, 2010; Tuzzolo and Hewitt, 2006). The purpose of this study is to examine whether a school-to-prison pipeline exists in eastern Oklahoma, and if so, to better understand the characteristics of the public schools that may be contributing to it. The school-to-prison pipeline metaphor guided three research questions regarding whether certain public schools in eastern Oklahoma referred greater percentages of their students, special needs students, and special needs population to the Oklahoma Office of Juvenile Affairs (OJA), the juvenile authority in Oklahoma. To answer these questions a survey was conducted during the 2011 and 2012 academic school year that measured public school referrals of students, particularly special needs students, to the OJA in ten eastern Oklahoma counties. Further data were collected from the Oklahoma Department of Education on nine specific demographic variables to create a profile of each of the 154 schools in the sample population. Multiple regression analysis indicate that greater percentages of students referred by public schools to the OJA are related to (1) higher percentages of African Americans, (2) higher percentages of Native Americans, (3) higher percentages of students receiving a free or subsidized lunch, (4) higher percentages of male students, and (5) higher percentages of special needs students in the public school. The study provides policy recommendations that focus on intervention strategies that might prevent unnecessary (1) referrals to juvenile justice and (2) recommendations for future research.
\end{abstract}




\section{Acknowledgements}

In the big scheme of things this venture was so improbable. In 1985, the pride my parents experienced as I became the first person in my family to earn a bachelor's degree was secondary to the initial shock they felt when they realized that I was actually graduating. That being said, many excellent teachers and professors left an indelible impression on me.

John Ritchey at Jefferson Elementary taught me "quick" mathematics. Mrs. Klingman at West Jr. High believed in me. Mrs. Murray at Muskogee High School has had the most profound influence on my confidence. Dr. Tom Cottrell gave me a scholarship that allowed me to go to college. D.K. Cunningham championed my criminal justice degree at NSU and C.H. Parker made sure I graduated.

Those I must thank at NSU for my Master's Degree are not only my professors, but my friends, and colleagues. Charles, Ray, and Buster thank you so very much for supporting my efforts, you truly are special friends. Rob thank you for your dedicated support. Amanda, thank you for all you do every day to make our lives easier. Julia thanks you so very much for your skill and expertise and for sharing it. To Dean Bridgmon, thank you for everything you have done for me (and for making that putt). Cari, Mike, Frank, and Bill own the bulk of my education. I cannot put my gratitude into words my friends, probably because it is so deep inside me. I only wish Bill was here to celebrate with us. To my friend and colleague Mike Moyer I must thank you for being my sounding board through this experience. Many thanks for what you have done for me and my family.

To Ron Coplan many thanks. Your support and friendship is so special to me. I would like to thank the staff of the Oklahoma Office of Juvenile Affairs and Len Morris particularly for provided me the data. Each one of you owns a little piece of my doctorate and I will be forever 
thankful. I would also like to thank the staff at the Oklahoma Department of Education for their dedicated support not only for this research, but to the children of the State of Oklahoma.

At the University of Arkansas Dr. Valerie Hunt steered the ship. Thank you so very much for chairing my Ph.D. committee and being there each time I needed you. Dean Patricia Koski I am so very proud to have had you on both of my committees. It really does make me feel special to have you take the time from your massive responsibilities to help me. Dr. Brinck Kerr, I have learned so much in the last year under your tutelage and guidance. Thank you so very much for chairing my dissertation committee, I will forever remember this adventure as a positive experience. You have not only given me the confidence but the desire to meet the next challenge. Thank you seems far from enough. 


\section{Dedication}

This dissertation is dedicated to my family. To my wife Brenda, everything that has happened in our lives has been a positive because we are together. I am a lucky man. I married the most beautiful woman I ever saw. To my daughter Abby, I thank you for giving up a little dad time every now and then so I could pursue this dream. I promise we will make up for the lost time. Thanks Tyler for your support and understanding. A special dedication goes out to my brothers and sisters and, finally, Mom, this is for you and Dad. I miss him every day. 


\section{Table of Contents}

\section{INTRODUCTION}

A. Research Questions ................................................ 2

B. Justification for the Research....................................... 4

1. Policy Implications .................................... 5

2. Sociological Perspectives ................................. 7

3. Racial Disparities: Suspensions, Adjudications, and Prison ....... 9

4. Special Needs Students ....................................... 10

5. Gaps in the Extant Literature ..................................... 13

C. Objectives of the Research ...................................... 14

D. Summary of Following Chapters ................................ 15

\section{LITERATURE REVIEW}

A. Introduction ............................................... 17

B. The Nexus of Criminal Justice, Juvenile Justice and Public Education

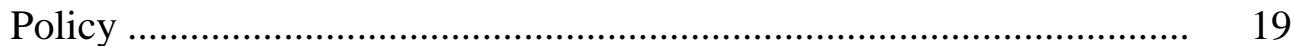

C. The School-to-Prison Pipeline .................................... 22

D. Contributing Factors to the School-to-Prison Pipeline Metaphor ........ 22

1. Zero-Tolerance .................................................. 23

2. School Resource Officers ........................................ 24

3. Special Education Laws: IDEA ............................. 26

4. Public School Educators Perceptions and Attitudes ............... 27

5. Poverty ........................................................... 29

6. Minorities ......................................................... 30

7. Special Needs Students .................................... 31

E. Indicators of a School-to-Prison Pipeline …......................... 31

1. Increases in Suspensions, Expulsions, and Adjudications .......... 32

2. Juvenile Justice Populations ...................................... 33

3. Juvenile Waivers to Adult Court .................................... 33

4. Incarcerated Populations ................................... 34

F. The Crime Control Model and Zero-Tolerance ...................... 35

G. Summary of Major Points in Extant Literature: State of Knowledge in the Field ......................................................... 36

H. Shortcomings of the Extant Literature ............................... 37

I. Research Hypotheses ............................................. 38

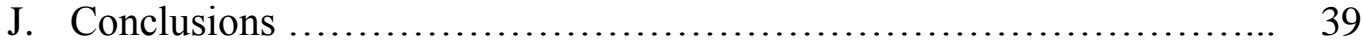

III. RESEARCH DESIGN

A. Research Questions ............................................... 41

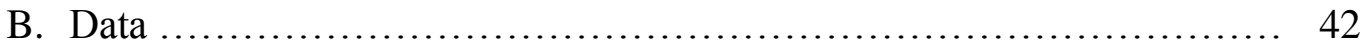

1. Population .................................................. 42

2. Data Collection from Oklahoma Office of Juvenile Affairs ....... 42

3. Data Collection from the Oklahoma Department of Education .... 45 
C. The Dependent Variables ........................................... 46

D. Independent Variables, Hypotheses, and Measurement .................. 47

E. Methods of Data Analysis ....................................... 50

\section{EMPIRICAL RESULTS}

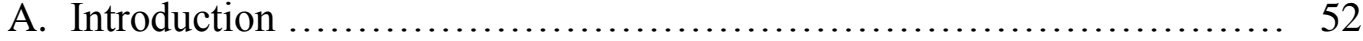

B. Description of the Sample ........................................... 53

1. Demographic Profile of District 5 of the OJA .................. 53

2. Public Schools in District 5 of the OJA ......................... 53

C. Descriptive Statistics ................................................... 54

1. Description of the Dependent Variables ............................. 54

2. Description of the Independent Variables ........................ 55

a. Independent Variables-Minority Enrollment ............ 56

b. Dichotomous Independent Variables ..................... 57

D. Multiple Regression Results ........................................ 57

1. Percentage of Students Referred to the OJA by the Public School ...................................................... 57

a. Correlations for Independent Variables ......................... 61

2. Percentage of Special Needs Students Referred to the OJA by the Public School............................................... 61

3. Percentage of a Schools' Special Needs Population Referred to the OJA by the Public School ................................... 64

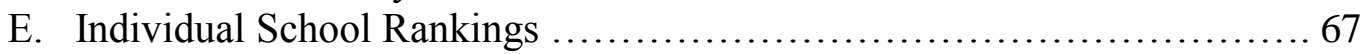

1. Dependent Variable 1: the percentage of students referred to the OJA divided by the total enrollment in the school ............. 67

2. Dependent Variable 2: the percentage of special needs students referred to the OJA divided by the total enrollment in the school ......68

3. Dependent Variable 3: the percentage of special needs students referred to the OJA divided by the total enrollment of special needs students enrolled in the school

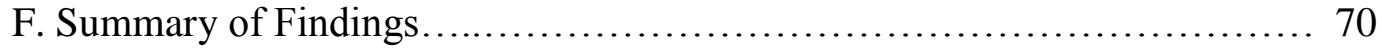

\section{SUMMARY AND DISCUSSION}

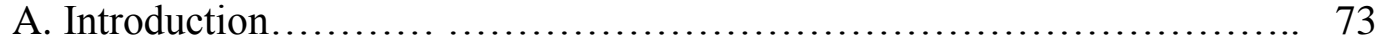

B. Summary and Discussion of Findings................................ 73

1. Research Question 1: Do some schools in eastern Oklahoma refer students to the OJA at greater rates than other school in eastern Oklahoma?

2. Research Question 2: Do some schools in eastern Oklahoma refer special needs students to the OJA at greater rates than other schools in eastern Oklahoma?

3. Research Question 3: Do some schools in eastern Oklahoma refer a greater percentage of their population of special needs students to the OJA than other schools in eastern Oklahoma? 


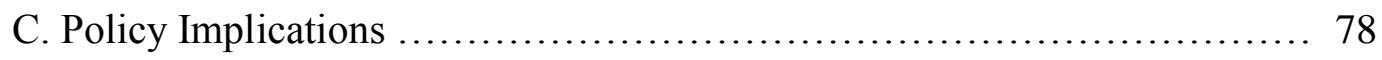

1. Disciplinary Policy .......................................... 78

2. Improving Intervention Strategies to protect at-risk students ........... 80

3. Policy Recommendations....................................... 81

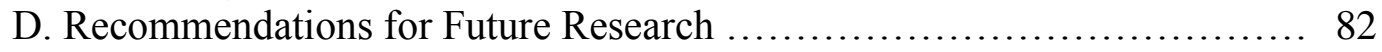

1. Discretionary Discipline ..................................... 82

2. Native American Students.................................... 83

3. African American Students..................................... 83

4. School Resource Officers ........................................... 84

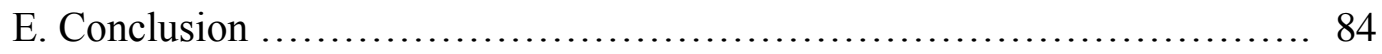

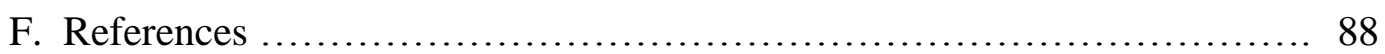




\section{Chapter 1}

\section{Introduction and Aims of the Research}

On October 24, 2012, a lawsuit was filed against Meridian, Mississippi for operating “a school-to-prison pipeline in which students are denied basic constitutional rights, sent to court and incarcerated for minor school infractions" (CNN, 2012). The federal civil rights attorneys that filed suit allege that the school district was engaging in activities that inappropriately criminalized student behavior including “...children who talk back to teachers, violate dress codes and commit other minor infractions" (CNN, 2012). Many studies suggest that the criminalization of typical student behavior by public schools has become the norm, not the exception (Johnson and Womack, 2013). In March of 2013, the Meridian Public School District entered into a consent decree with the Department of Justice (DOJ) intended to "decrease excessive suspensions and expulsions" of its minority students while reducing the use of police intervention (Mock, 2013, p. 2). The litigation is still pending, as a subsequent lawsuit was filed by the DOJ against the Meridian Police Department, the Lauderdale County Youth Court, and the State of Mississippi (Mock, 2013). While Meridian, Mississippi and federal attorneys continue to litigate the question, evidence that public schools are significantly contributing to the large numbers of minority, poor, and special needs students referred to juvenile justice agencies across the country remains largely under-researched (Wald and Losen, 2003).

This dissertation examines what the Council of State Governments (CSG) and the U.S. Attorney General are now calling a school-to-prison pipeline (OJJDP, 2011). The allegations associated with the school-to-prison pipeline metaphor include the overrepresentation of poor, minority, and special needs students currently involved in juvenile justice systems throughout the United States. Much of the scholarly literature suggests that the school-to-prison pipeline is the 
result of changes in special education policy, including recent amendments to the Individuals with Disabilities Act (IDEA), zero-tolerance policies adopted by the schools, increases in suspensions and expulsions, increased dropout rates, the use of school resource (police) officers to criminalize student behavior, and policies that may target poor, minority and special needs students enrolled in public schools (Advancement Project, 2007; Comstock-Galagan and Brownstein, 2006; Raskin 2004; Tulman and Weck, 2009). The school-to-prison pipeline "represents the ways in which the failures of school systems to educate our children contribute to the increase in the juvenile justice and prison population" (Tulman and Weck, 2009, pp. 876877).

Too often the latent consequences of current public education policy for at-risk ${ }^{1}$ students include suspensions, expulsions, juvenile delinquency adjudications, waivers to adult court, and prison. The lessons learned by the Meridian Public School District in Meridian, Mississippi should serve as an example to other school districts leaning too heavily on the juvenile justice system to discipline their students. Outcomes of public education should be graduation, college, employment, healthier lifestyles, and good citizenship.

\section{Research Questions}

This research will examine the referral of students, including special needs students, from public schools in eastern Oklahoma to the Oklahoma Office of Juvenile Affairs (OJA), the juvenile justice authority in Oklahoma. This research is intended to identify whether certain public schools in eastern Oklahoma are referring their students to juvenile justice agencies at

\footnotetext{
${ }^{1}$ An at-risk child is "any child or youth who, due to disabling, cultural, economic, or medical conditions, is (a) denied or has minimum equal opportunities and resources in a variety of settings and (b) is in jeopardy of failing to become a successful and meaningful member of his or her community" (Leone et al., 2003:p.6).
} 
greater rates than others and to identify the statistically significant factors associated with referral of students to the (OJA). This study addresses the following research questions:

1. Do some schools in eastern Oklahoma refer students to the Oklahoma Office of Juvenile Affairs (OJA) at greater rates than other schools in eastern Oklahoma?

2. If so, why?

3. Do some schools in eastern Oklahoma refer special needs students to the Oklahoma Office of Juvenile Affairs (OJA) at greater rates than other schools in eastern Oklahoma?

4. If so, why?

5. Do some schools in eastern Oklahoma refer a greater percentage of their population of special needs students to the OJA than other schools in eastern Oklahoma?

6. If so, why?

The following independent variables will be examined in order to answer each of the research questions in this study:

1. The percentage of special needs students enrolled in the school

2. The percentage of students receiving a free or subsidized lunch enrolled in the school

3. The percentage of male students enrolled in the school

4. The percentage of out-of-school suspensions per enrollment in the school

5. The percentage of African American students enrolled in the school

6. The percentage of Latino students enrolled in the school

7. The percentage of Native American students enrolled in the school

8. The presence of a male principal in the school

9. The presence of a school resource officer at the school 


\section{Justification for the Research}

Justification for this dissertation is divided into five distinct categories: (1) policy implications, (2) sociological perspectives, (3) racial disparities, (4) special needs children, and (5) gaps in the current literature. The policy implications associated with a school-to-prison pipeline apply to public education policy, mental health policy, juvenile justice policy, and adult criminal justice policy. Public schools may be marginalizing groups of students by criminalizing their behavior instead of addressing it within the framework of traditional school disciplinary actions. The sociological perspectives associated with a school-to-prison pipeline metaphor are numerous and will be addressed in the literature review. Financial and societal costs including the harm a school-to-prison pipeline has on our nation's youth is of particular concern. Racial disparities still exist in public education as evidenced by the overrepresentation of children of color in school suspensions, expulsions, delinquency adjudications, and waivers to adult court (Beck and Muschkin, 2012; Laura, 2011; Lynn, 2009). Special needs children have been particularly harmed by public school policy. There exists today significant evidence that special needs children are vastly overrepresented in juvenile justice populations across the country (Leone et al., 2002; Mears and Aron, 2003; Teske and Huff, 2010; Tulman, 2008; U.S. Commission on Civil Rights, 2002; Wald and Losen, 2003).

The poor, minority, and special needs students have been deemed at-risk youth in many cases. Public schools are tasked with the responsibility to provide these students with additional resources to enable them to have a positive educational experience ("Palm Beach," 2007; Comstock-Galagan and Brownstein, 2006; Raskin, 2004; Tulman and Weck, 2009). Too often these populations are provided a parsimonious educational experience that pushes them out of school and into the juvenile justice and adult criminal justice system ("Palm Beach," 2007; 
Comstock-Galagan and Brownstein, 2006; Raskin, 2004; Tulman and Weck, 2009). According to U.S. Attorney General Eric Holder, "ensuring that our educational system is a doorway to opportunity—and not a point of entry to our criminal justice system— is a critical, and achievable goal" (OJJDP, 2011, p. 1).

The literature review in chapter 2 connects all of these factors to the school-to-prison pipeline metaphor while highlighting gaps in the literature. The most significant deficiency in the literature is the lack of empirical studies that measure the actual migration of students from public schools to the juvenile justice system.

Policy implications. Recent criminal justice policies such as mandatory sentencing, three strikes legislation, and current drug laws have been designed to get tough on adult criminal offenders. These policies became popular during the 1980's as a response to the high crime rates that had been recorded during the 1970's. Ronald Reagan's "get tough on crime" agenda gave rise to federal and state legislative action designed to protect the public by increasing the incarceration of offenders, thus deterring would-be offenders from criminality. This is commonly referred to as the crime control model of criminal justice (Cole, 2013; Elrod and Ryder, 2005; Taylor and Fritsch, 2011). In the decades that followed, evidence suggests that the crime control model has infiltrated both public education and juvenile justice policy by creating a school-toprison pipeline that targets at-risk youth for delinquency adjudications and juvenile waivers to adult court. According to Wald and Losen (2003), "adult prisons and juvenile halls are riddled with children who have traveled through the school-to-prison pipeline" (Wald and Losen, 2003, p. 11).

In 2011, a collaborative effort was begun by the U.S. Attorney General Eric Holder and U.S. Secretary of Education Arne Duncan announcing the creation of the Supportive School 
Discipline Initiative. The initiative is designed to "target the school disciplinary policies and inschool arrests that push youth out of school and into the juvenile justice system" (OJJDP, 2011, p. 1). According to U.S. Attorney General Eric Holder, the "use of excessive and inappropriate school disciplinary practices too often contribute to the school-to-prison pipeline" metaphor (OJJDP, 2011, p. 1). Inappropriate disciplinary practices include the criminalization of petty offenses by the school. Many of these offenses should be handled informally. School disciplinary practices in many instances tend to be harsh and have "jailed children who could be disciplined within their homes or classrooms, altering their lives forever" (Tuzzolo and Hewitt, 2006, p. 61).

The school-to-prison pipeline puts children at risk for a lifetime of unemployment, poverty, delinquent and criminal activity, juvenile and adult incarceration, substance abuse, and unstable relationships (Leone et al., 2003). According to Hatt (2011), nearly all the states currently have "laws that encourage the prosecution of juveniles as adults, where they are at a higher risk of not only attack and rape, but of suicide" (p. 478). Increased victimization to juveniles is only part of the equation. When schools marginalize students, their subsequent victimization of the public may increase. In a 2007, the U.S. Centers for Disease Control and Prevention "concluded that sending children to the adult criminal justice system increases crime" (Tulman, 2008, p. 22). "Students who are suspended from the classroom are more likely to drop out, which in turn increases the likelihood they will be incarcerated later in life" (Johnson et al., 2013, p. 2). Every attempt should be made to identify the predictors of incarceration with the intent of developing better public policies that provide lifelong positive outcomes for our children. The first step should be to shut the door on the school-to-prison pipeline. 
Determining if some schools are contributing to an overrepresentation of special needs, poor, and minority students in the juvenile justice system in eastern Oklahoma is essential when providing policy suggestions to practitioners seeking to address the school-to-prison pipeline dilemma. Studies that measure the migration of special needs students from public schools to juvenile justice agencies are urgently needed (Brown et al., 2008; Wald and Losen, 2003). This research will determine if certain public schools in eastern Oklahoma are disproportionately referring students to the OJA and will identify and evaluate the factors that may be associated with the referral of these students.

If a significant relationship exists between certain independent variables and public school referrals to the OJA, this evidence may be consistent with the school-to-prison pipeline metaphor. This would also fill a significant gap in the literature. Evidence that suggests the presence of a school-to-prison pipeline can also be used as catalyst for the reexamination of school disciplinary policies and practices. Policy makers can use these findings and policy recommendations in their efforts to change education policy to effectively reduce referrals of students to juvenile justice agencies as well as to help the OJA develop policies to better address the needs of at-risk children.

Sociological perspectives. Keeping children in our public schools is not only the right course of action, it is cost-effective. In a study on truancy, Ingersoll \& LeBoeuf (1997) suggest that "some students who are not in school are busy committing crimes such as burglaries, vandalizing cars, shoplifting, and scrawling graffiti on signs and office buildings" (p. 4). This is only compounded when they are no longer attending school. The costs associated with students who do not complete high school or receive a high school diploma not only detrimental to the student, but to society as a whole. According to McIntosh et al. (2008), "students who do not 
complete high school cost taxpayers billions of dollars in lost revenues, welfare, unemployment, crime prevention, and prosecution" (p. 243).

Students in eastern Oklahoma may be particularly vulnerable to the consequences of a school-to-prison pipeline. An article in the Tulsa World (2012) indicates that 51 percent of “...young children whose parents do not have a high school degree live in poor families" (p. 1). The U.S. Department of Education's latest annual report also ranks Oklahoma $49^{\text {th }}$ in per pupil expenditures while " $73 \%$ of eighth graders cannot read nor do math at an eighth grade level" (Anderson, 2012, p. 1). According to the U.S. Census American Community Survey, 15.2 percent of persons over the age of 25 in Oklahoma have less than a high school education (U.S. Census, 2010). Lack of educational attainment and poverty continue to be significant issues in eastern Oklahoma.

The migration of special needs students into the juvenile justice system results in significant budget concerns for juvenile justice agencies. The cost to house residents in a juvenile detention facility can be as much as three hundred fifty $(\$ 350)$ dollars per day, which is considerably more expensive than leaving the student in school and providing community based mental health services (Kresnak, 2004). "In Oregon, it costs roughly $\$ 66,000 /$ year to incarcerate a youth (Waintrup and Unruh, 2008, p. 129). While costs for juvenile justice services are increasing, "many legislators now confront the need to make drastic cuts in state and local budgets, they desperately need information about how targeted investments in education can reduce expenditures in corrections" (Wald and Losen, 2003, p. 12). The consequences of the crime control model include increased suspensions, expulsions, referrals to juvenile justice, and adult adjudications for minorities, poor students, and students with special needs. 
Racial disparities: suspensions, adjudication, and prison. Current education policy

and practices have created difficulties for groups of students who are traditionally disadvantaged. In a study conducted by the American Psychological Association (APA) in 2004, "Hispanics were 1.23 times more suspended than whites, Native Americans were 1.52 times more suspended than whites, and blacks were 2.84 times more suspended than whites” (Lynn, 2010, p. 96). Tuzzolo and Hewitt (2006) conducted a study that showed in 2000, African American students accounted for 34 percent of student suspensions in the U.S. and 45 percent of the arrests while comprising only 17 percent of public school enrollment (p. 61). African Americans make up a large percentage of the criminal justice and juvenile justice systems' population "despite the fact that African Americans do not perpetrate the majority of crimes" (Morris, 2011, p. 6). "In 1998, black youths with no prior criminal records were six times, and Latino youths were three times, more likely to be incarcerated than whites for the same offenses" (Wald and Losen, 2003, p. 10).

Much of the literature points to lower graduation rates and higher incarceration as evidence of school failure and the school-to-prison pipeline dilemma. According to Wald and Losen (2003), nearly 70 percent of the 1997 prison populations in the U.S. had not completed high school, and "in the one hundred largest cities in the United States, 58 percent or more of ninth-grade students in high-minority schools do not graduate four years later" (Wald and Losen, 2003, pp. 9-10). Not completing high school is a predictor of adult incarceration among these groups. The school-to-prison pipeline metaphor indicts the processes schools use to socialize, discipline, and educate students. The lack of educational attainment among at-risk students explains how many of these students end up in prison (Hatt, 2011, p. 477). According to Wald and Losen (2003), "the single largest predictor of later arrest among adolescent females is having been suspended, expelled, or held back during the middle school years" (p.11). When students 
drop out of school they “...pose significant problems for school administrators, police officers, juvenile court judges, probation officers, and the public" (Ingersoll and LeBoeuf, 1997, p. 2).

It is estimated that over 500,000 youth are adjudicated delinquent each year (Ingersoll and LeBoeuf, 1997). Once a juvenile has been referred to juvenile justice and is an adjudicated delinquent, one of two dispositions are possible. The juvenile either remains in the community or is temporarily placed outside of the home in a residential facility. The juvenile will be required to continue to attend school or return to school upon release from the residential facility.

Maintaining an educational plan is critical to reducing recidivism among these youth.

Particularly problematic is the likelihood that they will be stereotyped. "These youth frequently face parents who have given up on them, teachers and fellow students who fear them and citizens who do not want them in the community" (Ingersoll and LeBoeuf, 1997, p. 6). Research clearly indicates that the majority of these adjudications involve youth of color (Lamarche, 2011; Morris, 2011; Wald and Losen, 2003). While much of the research suggests that suspensions, expulsions, and adjudications are racially biased, utilizing waivers that remove children from juvenile court to adult court is biased as well. Although African American students have a disproportionate number of their cases referred to adult court, a study by The Building Blocks for Youth (1998) found:

43\% of African American youth prosecuted in adult courts were not convicted; in contrast; $28 \%$ of Latino youth and $24 \%$ of white youth were not convicted. African American youth also were much more likely to have their cases transferred back to juvenile courts than white youth. (Leone et al., 2003, p. 15)

These patterns suggest that juvenile justice and public school policies may target minority youth for sanctions that are more severe than those for white youth.

Special needs students. The Individuals with Disabilities Education Act (IDEA) evolved from the Elementary and Secondary Education Act (ESEA) of 1965 and became law in 
1990. The IDEA (the current law governing special education) was reauthorized in 1997 and 2004 (U.S. Dept. of Ed., 2007). The IDEA requires schools to provide a free and appropriate public education to students with disabilities in the least restrictive environment and maintain an individual education program (IEP) for each of these students including behavioral intervention strategies (U.S. Dept. of Ed., 2007).

Senator Bob Dole (R-Kansas) in support of the 1997 amendments and subsequent reauthorization of the IDEA indicated that the discretion provided to educators to maintain safer schools can be achieved "without sacrificing any of the important protections IDEA gives students with disabilities" (Congressional Record, 1996, p. 1). However, research suggests that public schools through implementation of the amendments to the IDEA have diluted schools' responsibilities to ensure special needs students access to a free and appropriate public education in the least restricted environment (National Council on Disability, 2002, p. 6). The fact that "students with disabilities display higher rates of problem behavior and disciplinary referrals than their other classmates" (The National Center on Education, Disability, and Juvenile Justice, 2003 , p. 2) is directly related to the significant number of juveniles with disabilities placed in the juvenile justice system. "One of the key elements of the original IDEA, as conceived in 1975, was the recognition that, for children with behavioral disorders, access to school is meaningless if it does not include programming that addresses behavioral needs" (U.S. Commission on Civil Rights, 2002, p. 10). Much of the literature suggests that the recent amendments to the IDEA provide too much flexibility or discretion to public schools and this is another reason why the door to the "school to prison pipeline" has been opened (Leone et al., 2002; Teske and Huff, 2010; Tulman, 2008; Wald and Losen, 2003). 
The amendments to the IDEA in 1997 included 20 U.S.C. sections 1415(k) (9) (A) and (9) (B). These new sections to the IDEA allow schools to initiate arrest of a student with learning disabilities if they commit a crime (Raskin, 2004). Under many circumstances the decision to criminalize a special needs student's behavior is at the sole discretion of the school. According to the U.S. General Accounting Office (2003), school administrators prefer to rely on the juvenile justice system to handle disciplinary problems within the schools (p. 9). The U.S. Commission on Civil Rights (2002) suggests that much of the "behavior that can be attributed to a disability is commonly mischaracterized as misconduct and treated with discipline rather than appropriate services" (U.S. Commission on Civil Rights, 2002, p. 10).

Studies have indicated that special needs students are particularly vulnerable to delinquency adjudication (Leone et al., 2002; Teske and Huff, 2010; Tulman, 2008; Wald and Losen, 2003). Many students involved in the juvenile justice system began their pathway to detention as a special education student in public school. Houchins et al. (2010) report that among incarcerated males in one study, "forty-four percent of students had an identified disability" (p. 61). Some studies indicate that as many as 70 percent of the youth in the juvenile justice system are special education students (Tulman, 2008; Wald and Losen, 2003). The overarching concern for parents of special needs children is that their child will be denied an education because the schools do not want to deal with behavioral issues. "Parents of disabled children, having learned from history, worry that their children's access to the regular public school may be curtailed by school discipline rules, not because of any serious concerns about safety, but merely because their children may be difficult to teach" (Boothby, 2002, p. 2). For African American special education students, “...the risk factors are particularly high” (Wald and Kurlaender, 2003, p. 36). 
Under the guidelines of zero-tolerance policies and school safety protocols, special needs students may be targeted for severe consequences while there is no evidence that schools are safer. Some researchers believe that it is the school's responsibility for not providing necessary services to special needs students and that is why there are a disproportionate number of special needs students removed from school settings (Leone et al., 2003, pp. 1-3). Special needs students who have been adjudicated are more likely to experience lifelong difficulties than non-special needs students. "Juvenile offenders with some type of disabling condition are disproportionately represented in the juvenile justice system and are even more vulnerable to poor employment and life outcomes than their non-disabled peers" (Waintrup and Unruh, 2008, p. 128).

What we do know is that the percentage of young people in juvenile correctional facilities who were previously identified and served in special education programs before their incarceration is at least three to five times the percentage of the public school population identified as disabled. (Leone, 1997, p. 2)

However, there is no indication how many of these students were referred to juvenile justice by the schools.

Gaps in the extant literature. Studies that measure juvenile justice populations do not measure school referrals to juvenile justice (Lamarche, 2011; Tuzzolo and Hewitt, 2006; Wald and Losen, 2003). Determining whether the incident that resulted in the arrest happened at school or whether the incident did not involve the school is elusive. What is even more disturbing is that studies on the school-to-prison pipeline metaphor ignore students placed on probation and tend to focus only on incarcerated youth (Brown et al., 2008). Research has not examined whether non-incarcerated youth who are involved with the juvenile justice system demonstrate academic problems similar to their incarcerated counterparts (Brown et al., 2008). Although research has exposed the fact that there are huge numbers of incarcerated special needs students and has theoretically constructed a school-to-prison pipeline metaphor associated with at-risk 
youth, studies that measure the migration of special needs students from public schools to juvenile justice agencies need to be conducted (Wald and Losen, 2003). What we do not know is how many referrals public schools are making to juvenile justice agencies or which factors, if any, contribute to those referrals. Nor do we know how many special needs students are being referred.

The need to understand the impact public schools are having on our juvenile justice populations is imperative when developing policy to reduce juvenile justice and prison populations (Ingersoll and LeBoeuf, 1997), reducing incarceration costs (McIntosh et al., 2008;

Kresnak, 2004; Wald and Losen, 2003), and reducing racial disparities in our correctional system (Morris, 2011; Lynn, 2010) .

\section{Objectives of the Research}

This research fills an important gap in the current literature by measuring and evaluating the referrals made by public schools in eastern Oklahoma to the OJA. This research also evaluates the profiles of public schools to see if a statistically significant relationship exists between key factors and the percentage of referrals by the public school to the OJA. This research focuses primarily on special needs students, but it also evaluates referral of all students to the OJA. The study uses data collected during the OJA intake process and data collected from the Oklahoma Department of Education during the 2011-2012 academic school year (August $15^{\text {th }} 2011$ through June $15^{\text {th }}$ 2012). Ten counties in eastern Oklahoma have been surveyed. A survey instrument was used by the OJA during the 2011-2012 academic school year to determine if students referred during this period had, or have ever had, an IEP. The survey instrument identified non-IEP and IEP referrals and whether a particular public school was the source of the referral. 
This dissertation employs quantitative methods in order to investigate the relationship between referrals of students to the OJA and several independent variables for 154 public schools in eastern Oklahoma. I examine three dependent variables: (1) The percentage of students referred by the school to the OJA, (2) the percentage of special needs students referred by the school to the OJA and, (3) the percentage of the school's special needs population it has referred to the OJA. This research is necessary in order to determine which factors are related to the public school referrals of special needs students.

\section{Summary of Following Chapters}

In Chapter 2 (Literature Review), the literature surrounding the school-to-prison pipeline metaphor will be reviewed. Current education policy is discussed as well as the negative effect of coupling juvenile justice with criminal justice policy. The literature review highlights the contributing factors to the school-to-prison pipeline, indicators of a school-to-prison pipeline, and the need for additional scholarly work that examines the school-to-prison pipeline metaphor.

In Chapter 3 (Research Design), I describe the public schools in eastern Oklahoma and explain how the dependent and independent variables are measured. I also explain that multiple regression is used to analyze the "effects" of nine independent variables on three different dependent variables. The characteristics of the data collected by the Oklahoma Department of Education (DOE) and the Oklahoma Office of Juvenile Affairs (OJA) within a ten county district in eastern Oklahoma are discussed. The data set includes the demographic profile of each school. This research design will answer questions about why some schools refer students, including special needs students, to the OJA at greater rates than do other schools.

In Chapter 4 (Empirical Results), the findings and data analysis for each research question are presented, including descriptive statistics for the dependent and independent 
variables. The chapter reports and interprets the multiple regression results. The findings for each model are compared to see if the same independent variables are significant in each of the three models.

Finally, in Chapter 5 (Conclusions), I provide a summary of the findings and use the findings to inform policy recommendations. Also, recommendations for future research are made based on the findings. The strengths and weaknesses of the research are also discussed. 


\section{Chapter 2}

\section{Literature Review}

\section{Introduction}

The school-to-prison pipeline metaphor, as constructed in the literature, includes an indictment of public education policy, juvenile justice policy, and criminal justice policy. Studies suggest that much of the public policy attributed to the school-to-prison pipeline metaphor can be politically motivated (Anderson, 2011). According to Anderson (2011), "social change, and the conflict that often accompanies it, stimulates demands for governmental action" (p. 45). The literature suggests that media sensationalism of school violence, the juvenile superpredator ${ }^{2}$, and increases in adult crime have had a major effect on the political decision-making process since the 1980's (Elrod and Ryder, 2005; Taylor and Fritsch, 2011). "By dramatizing or downplaying the problem and by declaring what is at stake, these descriptions help to push an issue onto the front burners of policymaking" (Rochefort and Cobb, 1994, p. 3). During the Reagan and Bush eras adult crime and juvenile crime dominated the media. During this period, fear of crime grew which "...led the public to demand a tougher juvenile justice system, one that relied more on punishment and sending a tough message to would-be offenders" (Reddington and Bonham, Jr., 2012, p. 179). It was believed that deterring would-be criminals from criminal acts was a byproduct of getting tough on crime. Over time these "get tough" policy changes have increased incarceration rates in the juvenile justice and adult criminal justice systems (Elrod and Ryder, 2005; Reddington and Bonham, Jr., 2012; Taylor and Fritsch, 2011). During the same period,

\footnotetext{
${ }^{2}$ Juvenile superpredator is a term coined by criminologist John Dulia to describe youths who have become "more aggressive, more violent, and increasingly less susceptible to treatment" (Taylor \& Fritsch, 2011:p.67)
} 
public school systems adopted similar "get tough" polices that may have contributed to increases in the juvenile justice and criminal justice populations.

Tulman (2008) suggests that significant increases in juvenile justice and criminal justice populations are the residue of harsh disciplinary practices adopted by public schools. Previous research indicates that systemic predictors of a school-to-prison pipeline include zerotolerance/safety first polices, law enforcement placed in public schools (SRO's), and changes in special education policy that have diluted the school's responsibility to protect special needs children (Leone et al., 2003; Raskin, 2004; Tulman, 2008; Wald and Losen, 2003). Negative teacher attitudes and harsh disciplinary practices by public schools often push students out of school through increased suspensions and expulsions or, in many instances, by criminalizing petty offenses that can easily be interpreted as normal student behavior (Aull, 2012; Beger, 2002; Boothby, 2002; Elrod and Ryder, 2005; Leone et al., 2003; Price, 2009; Raskin, 2004; Taylor and Fritsch 2011; Tulman, 2008; Wald and Losen, 2003).

Along with the aforementioned factors, the literature includes a demographic profile of the school-to-prison pipeline. Poverty, race, and special needs may be the biggest predictors of a student becoming involved in the juvenile justice and criminal justice systems. The overrepresentation of these populations in the juvenile justice and criminal justice systems suggests they may be particularly vulnerable under current public education policy for referral to law enforcement (Aron and Mears, 2003; Capella et al, 2008; Laura, 2011; Lynn, 2009; Tullman and Weck, 2009).

The literature is replete with evidence of public education's systemic failure to keep atrisk populations in school. This evidence includes the overrepresentation of minority, poor, and special needs students in (1) suspensions and expulsions from public school, (2) juvenile justice 
populations, (3) juvenile waivers to adult court, and (4) adult incarcerated populations (Adams and Addie, 2010; Hatt, 2011; Teske and Huff, 2010; Tulman, 2008; Wald and Losen, 2003).

Below I (1) discuss the nexus of criminal justice, juvenile justice and public education policy, (2) describe the school-to-prison pipeline metaphor, the indicators that it exists, and factors indicated in the literature that contribute to it, (3) present the theoretical basis for my research, (4) summarize the major points in the literature, (5) identify any relevant gaps in the literature, and (6) provide the reader with the research hypotheses.

\section{The Nexus of Criminal Justice, Juvenile Justice, and Public Education Policy \\ “As punishments become more cruel, men's minds, adjusting themselves like fluids to the levels of surrounding objects, become increasingly hardened"}

Cesare Beccaria (1765)

Beginning in the 1980 's, a series of policies was enacted to address the escalating crime rate within the U.S., including the national initiative to "get tough on crime" (Cole and Smith, 2010, p. 12). Tougher laws were deemed necessary to curb escalating violent crime, property crime, and drug abuse within our society and the "crime control model" of criminal justice was initiated. The crime control model "...emphasizes efficiency and the capacity to catch, try, convict, and punish a high proportion of offenders; it also stresses speed and finality" (Cole and Smith, 2010, p. 12). The adult criminal justice system has gone through several changes and uses its own treatment modalities to attempt to rehabilitate adult offenders. As a subset of the criminal justice system, the juvenile justice system is tasked with the same responsibility to rehabilitate offenders, reduce crime, and protect their communities (Elrod and Ryder, 2005, p. 12). 
The criminal justice system was divided in the early 1900's by introducing a separate juvenile justice system to function within the principle of parens patriae ${ }^{3}$ (state as the parent), and the rehabilitation of juveniles was accepted as a distinct and primary goal for the new system (Elrod and Ryder, 2005; Taylor and Fritsch, 2011). The traditional assumptions associated with the juvenile justice system focused on criminal intent (mens rea) because it is believed that juveniles are less culpable for their crimes than adults (Elrod and Ryder, 2005; Taylor and Fritsch, 2011). Juveniles are not fully developed biologically, psychologically, and sociologically. The traditional biological assumptions suggest that juveniles are not fully developed and lack the physiological capacity to control their behavior (Taylor and Fritsch, 2011). The psychological assumption is based on a lack of maturity and the inability for some juveniles to fully comprehend the consequences of their actions (Taylor and Fritsch, 2011). Many sociological factors, especially peer relationships and home environment, are posited as predictors of negative behavior (Elrod and Ryder, 2005; Taylor and Fritsch, 2011). Early child advocates were able to convince policy makers to adopt a new system for juveniles grounded in the concept of in loco parentis ${ }^{4}$ based on these assumptions.

Within the legal concept of in loco parentis, juvenile justice policy traditionally functioned with an understanding that juveniles needed no due process protections; a benevolent judge acting as a parent would prescribe treatment first, and then apply sanctions only if necessary. By the end of the 1970's, it was perceived that the juvenile justice system was not

\footnotetext{
3 "A legal doctrine in which the state assumes the role of the parent" (Taylor and Fritsch, 2011).

${ }^{4}$ The legal concept of allowing the state to act in place of the parents thus giving the state the legal right to take away parental custody of children when it is in the best interest of the child (Taylor and Fritsch, 2011).
} 
working as intended and, through a series of decisions, the Supreme Court ${ }^{5}$ incrementally granted children most of the rights guaranteed adults by the Constitution. It was during this period, spanning the late 1970's to early 1980's, that juvenile crime rose significantly (Elrod and Ryder, 2005). Political pressure during the 1980's prompted the criminal justice system and the juvenile justice system to adopt a more punitive system of justice that mirrored the adult crime control model of justice (Elrod and Ryder, 2005; Taylor and Fritsch, 2011). Both systems had seen increases in their populations, and the media had begun to sensationalize violent crime, especially juvenile violent crime. As juvenile crime continued to rise, "the media fueled public sentiment that juvenile crime was getting out of control and that rehabilitation did not work" (Reddington \& Bonham, Jr., 2012, pp. 179-180). The issue of school safety was brought to the forefront in the 1990's by national exposure to incidences of violence in school. "The events of Columbine, Paducah, Pearl, and Jonesboro were thought to be a wake-up call to our nation" (Boothby, 2002, p. 7). The assumptions that had initiated a separate juvenile justice system were essentially eroded in favor of more punitive policies in an attempt to address societal pressures without considering the possible consequences. "Policy shifts in the juvenile justice systems are more about changing assumptions than they are about actual practice, empirical study, or philosophic reasoning” (Taylor \& Fritsch, 2011, p. 37).

Consequences of these changes were zero-tolerance and safety-first policies adopted by public schools that many identify as a major component of the school-to-prison pipeline metaphor. During the 1990's, "forty-nine states and the District of Columbia changed their laws to try more children in criminal court and incarcerate more children in adult jails and prisons"

\footnotetext{
${ }^{5}$ See Kent v. United States 383 U.S. 541 1966; In re Gault 387 U.S. 1 1967; In re Winship 397 U.S. 358 1970; Breed v. Jones 421 U.S. 5191975.
} 
(Tulman, 2008, p. 22). Also in the 1990's, “school suspensions and expulsions rose dramatically as a consequence of national, state , and local zero-tolerance policies" (Tulman, 2008, p. 22). "In the wake of recent high-profile campus shootings, schools have become almost prison-like in terms of security and in diminishing the rights of students" (Beger, 2002, p. 119).

\section{The School-to-Prison Pipeline}

The critical issues that are created by the intersection of criminal justice, juvenile justice, and education policy are expressed in the literature as a school-to-prison pipeline metaphor. The literature suggests that public schools enact policies that unnecessarily criminalize the nonviolent acts of their students, partner with law enforcement agencies to police their schools and remove students, and enact safety first/zero-tolerance policies that target at-risk students ultimately pushing them out of school (Comstock-Galagan and Brownstein, 2006; Raskin, 2004; Tulman and Weck, 2009). The literature further indicates that negative teacher attitudes regarding inclusion/mainstreaming and bureaucratic discretion contribute to the exclusion of many juveniles from the education to which they are entitled (Aull, 2012; Price, 2009; Tulman, 2008). The punitive practices associated with the crime control model and adopted by the juvenile justice system may have become justification for public schools to arrest and remove large numbers of students while avoiding traditional intervention strategies that may be more appropriate (Aull, 2012; Beger, 2002; Leone et al., 2003; Price, 2009; Raskin, 2004; Tulman, 2008; Wald and Losen, 2003).

\section{Contributing Factors to the School-to-Prison Pipeline Metaphor}

The disciplinary policies and procedures utilized by public schools that result in the removal of students from educational settings and lead to juvenile justice and criminal justice adjudications are the systemic predictors of a school-to-prison pipeline. The school-to-prison 
pipeline metaphor includes the application of zero-tolerance policies, the use of SRO's, current special education laws, administrator/teacher attitudes and perceptions, and discretionary application of disciplinary protocols that negatively affect at-risk students in public schools (Aron and Mears, 2003; Beger, 2002; Meiners, 2011; Tuzzolo and Hewitt, 2006).

Zero-tolerance. Education and juvenile justice policy should be designed to provide for the best interests of the child. Public schools have the primary responsibility to educate children and maintain a safe learning environment. Juvenile justice has the responsibility to protect the public while protecting the interests and welfare of children (Jackson, 2002; Taylor and Fritsch, 2011). These two highly political institutions intersect at the issue of safety: maintaining safe school environments and protecting the public. In an effort to make schools safer, "during the 1980's and 1990's, the nation responded to the perceived juvenile crime wave of the time with drastic and dramatic policing of our children inside our public schools" (Tuzzolo and Hewitt, 2006, p. 61). During this period, public schools adopted zero-tolerance policies that have nearly doubled suspensions and have adopted school policy that mandates the "referral of children to law enforcement authorities for a variety of school code violations" (Wald and Losen, 2003, p. 10). Minor offenses that had traditionally been handled within the school are now the domain of law enforcement. "Under recent zero tolerance initiatives, trivial forms of student misconduct that were once handled informally by teachers and school administrators are now more likely to result in police arrest and referral to juvenile or adult court" (Beger, 2002, p. 123).

In addition to its effect on children, zero-tolerance is expensive: It's estimated that zero-tolerance and harsh discipline policies can cost states such as Mississippi and Louisiana hundreds of millions of dollars every year, and those costs continue for years to come in the form of lost tax revenue, higher health costs, higher public-assistance costs, and increased criminal-justice costs. (Johnson and Womack, 2013, p. 2) 
Studies have indicated that a student who graduates from school is less likely to engage in criminal activity (Leone et al. (2003); Teske and Huff, 2010). According to Teske and Huff (2010), "the problem with zero tolerance is that it removes children from school, when school is the second-most-important protective factor ${ }^{6}$ against delinquency and other negative behaviors" (Teske and Huff, 2010, p. 3). Leone et al. (2003) suggest that "the rise of zero tolerance in school settings serves as the paradigmatic example of the growth, and the peril, of punitive approaches to misconduct and control" (p. 2). According to the literature, it is within the framework of zerotolerance and the severity of punishment that a school-to-prison pipeline is predicted.

School resource officers. As zero-tolerance and safety-first policies began to dominate the educational landscape, more and more schools began to hire School Resource Officers (SRO) to enforce rules (Beger, 2002). Not only is it important to have safe schools, it is equally important for students and staff to feel safe while they are in school. Schools are now relying on law enforcement to achieve both goals (Jackson, 2002). According to May et al. (2004), SROs have four primary responsibilities:

1. Act as a liaison between the school, community, and police

2. Teach law-related education classes

3. Counsel students

4. Perform law enforcement duties

SRO's are generally commissioned law enforcement personnel from local law enforcement agencies (May et al., 2004).

According to a study conducted in Clayton County, Georgia, referrals to juvenile justice:

Increased approximately 1,248 percent immediately after police were placed on campuses. Approximately 90 percent of these referrals were misdemeanors involving

6 Family is the most important protective factor. 
school fights, disorderly conduct (mouthing off), and obstruction (not following the verbal command of a police officer), and disrupting school (throwing a wad of paper, shouting in class). (Teske and Huff, 2010, pp. 2-3)

A recent study reported that after introducing a large number of SRO's in one county in Ohio, school-based arrests "increased from 1,237 in the year 2000 to 1,727 in 2002" (Theriot, 2011, p. 2). While it is currently unknown exactly how many SROs/police officers are in our public schools, "it is estimated that there may be more than 20,000 law enforcement officers patrolling schools in the United States" (Theriot, 2011, p. 1).

While state legislators, teachers, and school administrators often support the presence of law enforcement in public schools, "limited empirical evidence exists to suggest that SROs are effective in increasing school safety" (May et al., 2004, p. 77). Despite this lack of evidence, some state legislatures, including Arizona, support having law enforcement involved in school discipline. In 2000, Arizona passed a law that requires school officials to report "any crimes or security threats involving students to the local police" (Beger, 2002, p. 122).

This clearly suggests that criminalization of student behavior increases dramatically when an SRO is introduced to the public school setting. There is also evidence in the research that students perceive the presence of SROs on school campuses as a threat (Jackson, 2002). Current studies on students' perceptions of having police officers on campus are revealing. Instead of feeling safe, students view the officers as an extension of the administrative disciplinarian in the school (Jackson, 2002). Some students feel they are being harassed and are more vulnerable for placement in juvenile justice detention centers (Jackson, 2002). Much of student apprehension to having police on campus is based on their negative stereotyping of the police in general (Jackson, 2002). Socio-economic status, male gender, and race are related to harsh student discipline within the public schools (Skiba et al., 2002; Welch and Payne, 2013). Increases in 
harsh school discipline of these groups contribute to distrust of police officers on the school campus (Jackson, 2002).

Special education laws: IDEA. Public Law 101-476, also known as the Individuals with Disabilities Education Act (IDEA), evolved from several legislative acts, including the Education for All Handicapped Act (EHCA) of 1975 (Pub. L. 94-142) and became law in 1990. With the IDEA, its subsequent reauthorization in 1997, and the Individuals with Disabilities Education Improvement Act of 2004 came many incremental changes. Currently, public schools are required to provide a free and appropriate public education (FAPE) to students with disabilities in the least restrictive environment. Although inclusion in regular (non-special education) classrooms was mandated, the legislation failed to mandate behavioral intervention strategies, including the positive behavioral supports (PBS) that the IDEA recommends (Department of Education, 2004). From the beginning, "one of the key elements of the IEP, as conceived in 1975, was the recognition that, for children with behavioral disorders, access to school is meaningless if it does not include programming that addresses behavioral needs" (U.S. Commission on Civil Rights, 2002, p. 10).

Changes to the IDEA focused on giving school administrators greater flexibility to maintain safer schools. In support of the 1997 amendments, Senator Bob Dole (R-Kansas) indicated that the discretion provided educators to maintain safer schools can be achieved "without sacrificing any of the important protections IDEA gives students with disabilities" (Congressional Record, 1996). By failing to mandate intervention strategies, special needs students may have been exposed to greater marginalization once entering regular classrooms (Department of Education 2004; Raskin 2004). Some negative behavior is expected from many students that have a disability, especially those with behavioral issues. Public schools cannot 
under the IDEA remove special needs students from their current educational setting for behavior that is determined to be a manifestation of their disability without first addressing the behavior in their IEP. However, changes to the IDEA allow schools to avoid the mandated IEP protocols when a student commits a criminal act (U.S. Dept. of Ed., 2007; Raskin, 2004). Research suggests that the implementation of the new IDEA has diluted the schools' responsibilities to ensure special needs students' access to a FAPE in the least restrictive environment (National Council on Disability, 2002; U.S. Dept. of Ed., 2007; Raskin, 2004).

Leone et al. (2002) argue that "many youth who are detained or committed to juvenile corrections have previously been assessed and identified as eligible for special education services, and were receiving special education and related services in public schools prior to their incarceration" (p. 34). Research suggests that many of the youth that end up in the juvenile justice system "might never have landed there had their disabilities and related needs been addressed" (Aron and Mears, 2003, p. 1). Once a special needs student acts out, decades of federally mandated protections no longer apply. "Special education students who are involved in serious misconduct are being disciplined in generally a similar manner to regular education students" (General Accounting Office, 2001, p. 6).

Public school educators' perceptions and attitudes. Townsend (2000) states that school failure can be the result of cultural differences between teachers and students as well as lowered expectations for minority students by teachers. African American students and their families are distrustful of public schools because they feel like they are overrepresented in "special education, remedial classes, alternative school placement, retention, suspension, and expulsion" (p. 389). This is especially troubling because school success or failure often depends on parental involvement in the education process. More and more, "elementary and secondary 
educators acknowledge the important role of family and community in the educative process as active positive contributors inside and outside the classroom" (Slaughter-Defoe and Carlson, 1996, p. 61). Some researchers believe that public schools are intentionally separating minority students by depositing them in alternative placements and giving them special education designations. "Classification as special education masks segregation, and pathologizing students of color as disabled allows their continued segregation under a seemingly natural and justifiable label" (Meiners, 2011, p. 552). According to the literature, these students become increasingly frustrated with their treatment in public school, and eventually they are either pushed out or they dropout. In either case, teachers play an important role in retention and dropout rates. They also play an important role in how student behavior is classified.

The biggest issue for teachers is their perception of safety in the classroom. "'Some emotionally disturbed kids [are] intimidating,' said one teacher. She went on to explain that she did not feel safe working with these students because administrators do not back teachers when an incident occurs with a child in special education" (Bon et al., 2006, p. 152). Teachers feel that the rights of the students trump their own, even when safety is the issue (Bon et al., 2006).

School safety is such a concern for teachers, verbal threats are viewed with the same anxiety as physical threats (Bon et al., 2006). Bon et al. (2006) conducted a qualitative study that attempts to measure teacher attitudes towards special needs children, the current IDEA, and school violence. Their study exposed significant concerns regarding school safety among teachers that clearly indicates the role of educators in the school-to-prison pipeline. The teachers defined school violence not only in the traditional sense (physical confrontations, fighting, weapons at school, and aggression), but they also identified disruptive behavior (verbal threats, lack of respect) as violent (pp.152-153). This broadening of the definition of violence may help 
to explain the increased criminalization of students as teachers interpret and report a wider spectrum of behavior.

Cook's (2004) study of 16 northeast Ohio elementary schools indicates that teachers can have negative attitudes toward special needs students that present an adverse learning environment (p. 307). According to Cook (2004), teachers are probably not attached to these pupils and often reject their presence in the classroom. From the beginning, some teachers have resisted the inclusion of special needs students in the regular classroom. Lieberman (1995) suggests that "general-education staff feel they were not trained to work with students with disabilities, had they chosen to work with special-education students, they would have sought appropriate training and looked for positions in that field" (p. 2). The literature suggests that concerns about safety in the classroom have led to an incremental policy shift from a focus on access to adopting discretionary policies in special education that restrict access based on safety first/zero-tolerance policy.

Poverty. Another significant factor associated with the school-to-prison pipeline metaphor is poverty. Much of the literature posits the stigma of being poor as a predictor of many negative outcomes including the failure of students in school (Capella et al, 2008; Nikulina et al., 2011; Tullman and Weck, 2009). "Children from low-income and minority families disproportionately populate the juvenile court, as well as juvenile shelter care, detention, and incarceration facilities" (Tullman and Weck, 2009, p. 876). Educational achievement is directly related to socioeconomic status and "research evidence suggests that race gaps in education are deeply rooted in poverty" (Beck and Mushkin, 2012, p. 640). Poverty is a significant predictor of school failure and juvenile delinquency. The "research on delinquent behavior provides consistent evidence that family socioeconomic background is the primary predictor of youth 
delinquency" (Beck and Mushkin, 2012, p. 640). Many of the studies indicate that school failure and delinquency are a result of disparities in educational opportunities. Some schools simply have more resources than others and poor students tend to attend under resourced schools.

In general, poor children with the least amount of access to high quality childcare, educational resources, healthcare, affordable housing, and nutrition are sent to the poorest schools while wealthy children, typically having access to those things listed previously, attend the wealthiest schools. (Hatt, 2011, p. 477)

Many of the youth in the juvenile justice system come from poor and/or single-parent families while "the rate of poverty is 50 percent higher among disabled youth than among other youth" (Osgood et al., 2010, p. 212).

Minorities. African American, Native American, and Latina students are suspended and expelled from public school at greater rates in the U.S. than white students (Hatt, 2011; Lynn, 2009). In 1999, a study by Gordon et al., of 11 major cities in the U.S. ranks the five major racial and ethnic groups according to the percentage of each population suspended and/or expelled during the school year. The sample included nearly two million students. Minorities' suspension and expulsion percentages were considerably higher than whites in the study. Nearly 13 percent (12.8) of African American students, 11 percent of Native Americans students, and 9.5 percent of Hispanic students were expelled or suspended during the 1999 school year while only 8.4 percent of whites where suspended or expelled (Lynn, 2009, pp. 95-96). In 2001,

Only 51 percent of American Indian, 53 percent of Hispanic, and 50 percent of Black students graduated in comparison to 75 percent of White students... although many of these youth have been framed as drop-outs, the truth is that many of them have been pushed-out. (Hatt, 2011, p. 478)

In 2008, 61 percent of one Chicago school district suspensions were comprised of African American males while only 23 percent of the district's student population was African American males (Laura, 2011). According to Townsend (2000), “...the intersection among African 
American ethnicity, male gender, and low family income increases students' risk for exclusionary discipline practices” (p. 382).

Special needs students. Special needs students are disproportionately represented in the juvenile justice system. Some studies suggest that as much as 70 percent of the juvenile justice population in the U.S. has special needs (Leone et al., 2002; Teske and Huff, 2010; Tulman, 2008; Wald and Losen, 2003). Special needs students are particularly vulnerable to zerotolerance policies and are "easy targets for punishment when they act out" (Teske and Huff, 2010, p. 3). Adjudicating special needs students is particularly devastating for both the individual and society. "Juvenile offenders with disabilities are a population with an incredibly high-cost to our society in terms of court, victim losses, incarceration costs, and reduced productivity from these adolescents" (Waintrup and Unruh, 2008, p. 129). Special needs students continue to make up the prominent demographic group in a juvenile justice system that has been crippled by insufficient resources.

The designation in the literature of these variables as correlates of school referrals relies on the presumed application of "get tough" policies by public schools. There is little empirical evidence that actually measures how many students are being removed from school through the use of juvenile justice referrals. What we do have is a clear indication that public schools have become increasingly more punitive while at-risk students receive a disproportionate share of the punishment. We simply have not previously measured the percentage of the juvenile justice population that can be attributed to school referral.

\section{Indicators of a School-to-Prison Pipeline}

Studies in the literature provide significant evidence of a school-to-prison pipeline. Increases in school suspensions and expulsions, increases in juvenile justice adjudications and 
incarcerated populations, and increases in the use of waivers to adult court are all suggestive of a school-to-prison pipeline (Adams and Addie, 2010; Tulman, 2008). The literature also suggests that increases in the incarceration of adult offenders lacking a high school diploma or equivalency are the result of failed education policies that push students out of school. In 1997, 68 percent of the prison population in the U.S. had not finished high school (Wald and Losen, 2003). The school-to-prison pipeline metaphor suggests that minority students, poor students, and special needs students are particularly vulnerable in the current educational environment (Hatt, 2011; Teske and Huff, 2010; Tulman, 2008; Wald and Losen, 2003).

Increases in suspensions, expulsions, and adjudications. School systems across the U.S. have safety policies that increase the use of suspensions and expulsions not only for violent offenses, but for a variety of non-violent behaviors. School suspensions and expulsions have risen dramatically over the last few decades (Teske and Huff, 2010; Tulman, 2008). "Many state legislatures and school districts have expanded the policy to include mandatory expulsions for drugs and alcohol, fighting, gang membership, threats, and/or swearing” (Hatt, 2011, p. 478). The school-to-prison pipeline is linked to school failure which is "linked to increased dropout rates, grade retention, and academic failure rates (Wald and Kurlaender, 2003, p. 36).

According to Tuzzolo and Hewitt (2006) in 2000, African American students accounted for 34 percent of student suspensions in the U.S. and 45 percent of the arrests while comprising only 17 percent of public school enrollment (p. 61). The same study indicated that in New Orleans during the 2004 and 2005 school year, 19 percent of its students experienced out-ofschool suspensions while one out of every ten students was expelled. A study conducted by Wald and Losen (2003) shows that "four out of every five new juveniles detained between 1983 and 1997 were youths of color" (p. 10). In 2006, another study showed nearly 3.3 million students 
were suspended nationwide (Lamarche, 2011). Studies also indicate that as many as 70 percent of the youth in the juvenile justice system are special education students, 68 percent of the prison populations in the U.S. in 1997 had not completed high school, and "in the one hundred largest cities in the United States, 58 percent or more of ninth-grade students in high-minority schools do not graduate four years later" (Wald and Losen, 2003, p. 11).

Juvenile justice populations. An issue addressed in previous studies is the relationship between school resource (police) officers and the school-to-prison pipeline (Tuzzolo and Hewitt, 2006; Wald and Losen, 2003). Research suggests that the partnership between schools and police agencies unfairly targets special needs students and increases the number of special needs students in the juvenile justice system. According to a Florida study, thousands of students had been referred to the juvenile justice system because school police officers "spend most of their time disciplining students for conduct that should be addressed by parent-teacher conferences, school programs, and counseling" ("Palm Beach," 2007, p. 2). The study further suggests that not only is this type of discipline happening across the U.S., but the criminalization of most of these students has little to do with school safety.

School districts across the country have teamed up with law enforcement to create this schoolhouse to jailhouse track by imposing a double dose of punishment- suspensions or expulsions and a trip to the juvenile court-for misconduct that often does not threaten school safety. ("Palm Beach," 2007, p. 2)

Juvenile waivers to adult court. Many states currently have laws that make it easier to move juveniles out of the juvenile justice system and into the adult criminal justice system. Beginning in the 1980 's, and continuing up to the present, these states have enacted legislation in an attempt to address juvenile violence that specifies under what circumstance a juvenile can be waived to the adult system. Between 1992 and 1999, waivers of juveniles to adult court have risen steadily as " 27 states extended the reach of judicial waiver laws, lowered age requirements, 
or otherwise broadened eligibility" (Adams and Addie, 2010, p. 2). From 1988 through 1992, "there was a 68 percent increase in judicially waived cases" (Reddington and Bonham, 2012, p. 183). Currently, 49 states have some form of waiver laws designed to get tough on juvenile offenders (Tulman, 2008). At-risk youth are not only vulnerable to excessive suspensions, expulsions, and referrals to juvenile justice systems that can lead to juvenile custodial placement; they are also vulnerable to incarceration in the adult criminal justice system (Hatt, 2011; Reddington and Bonham, 2012; Tulman, 2008; Wald and Losen, 2003). A public school system that excludes children from obtaining an education will ultimately contribute to prison populations. "The most common characteristic among incarcerated individuals are school failure $^{7}$ and illiteracy" (Leone et al., 2003, p. 15).

Incarcerated populations. Over 50 percent of the current population in prison has not graduated from high school. This is an alarming testament to our educational system and its ability to keep students in school where they are provided the best opportunity to establish the foundation for a productive life. "An estimated 34 percent of inmates in 1991 and 29 percent in 1986 had completed high school. In 1993, 17 percent of youth under the age of 18 entering adult prisons had not completed grade school" ${ }^{8}$ (Ingersoll and LeBoeuf, 1997, p. 2). In 2008, African American males between the ages of 20-34 were incarcerated at a rate of one out of every nine while one out of every 100 African American females had been incarcerated (Meiners and Winn, 2010). Data indicate that while "minority youth comprise approximately $1 / 3$ of the population under 18 , they represent approximately $2 / 3$ of all incarcerated youth" (Leone et al., 2003, p. 17).

\footnotetext{
7 "School failure includes retention in grade, dropping out, failure to graduate, and disciplinary exclusion" (Leone et al. (2003).

${ }^{8}$ Grade school in this context is referred to as eighth grade or less.
} 
A significantly higher rate of serious offenses committed by minority populations is a particular concern for criminal justice practitioners. "The homicide rate for black males is six times greater than for whites, and the homicide rate for Native American males was about three times greater than for whites" (Lynn, 2009, p. 100).

\section{The Crime Control Model and Zero Tolerance}

Public schools have adopted zero-tolerance policies and directives that often result in severe punishments. The punishments may include referrals to juvenile justice agencies while “...minimal evidence supports the argument that the threat of arrest and punishment deters juvenile delinquency" (Taylor and Frisch, 2011, p. 98). Zero-tolerance policies simply do not work, in fact, they make things worse.

Sadly, zero-tolerance policies are as [sic] ineffective as they are prevalent. Research shows that they fail to improve student behavior. Even worse, these policies deny students access to desperately needed services, while dramatically increasing the likelihood of future involvement with the juvenile justice system--especially for students of color. (Lamarche, 2011, p. 2)

My research is based within the conceptual framework that zero-tolerance policies are an application of the "crime control model" of criminal justice in public schools and these policies push students out of school by unnecessarily and inappropriately criminalizing their behavior. The theoretical basis of my research suggests that applying the "crime control model" in public schools within the framework of zero-tolerance and safety-first policy increases criminality by initiating the pathway to future criminal behavior. The overrepresentation of poor, minority, and special needs students currently included in criminal justice and juvenile justice populations suggests that they are particularly vulnerable to the application of the "crime control model" in public schools which, in turn, supports the existence of a school-to-prison pipeline. 


\section{Summary of Major Points in Extant Literature: State of Knowledge in the Field}

According to the literature, a school-to-prison pipeline is suggested by many factors. The implementation of zero-tolerance and safety-first policies has created a significant migration of children from public schools into the juvenile justice system. The application of the crime control model of criminal justice within public schools and juvenile justice systems has negatively affected the educational opportunity and rehabilitative outlook for at-risk youth. Many of these youth circumvent the juvenile justice system and go straight into the adult criminal justice system.

Many schools have opted to hire police officers or SRO's to protect the schools. "School resource officers are the fastest-growing segment of law enforcement officials stationed in public schools" (Beger, 2008, p. 121). Having police officers in the school has increased student criminalization, often for petty offenses that should be handled within the school (Tuzzolo and Hewitt, 2006). This can be viewed as evidence of the application of the crime control model of justice being applied in public schools especially as these students get pushed into the adult system (Elrod and Ryder, 2005; Taylor and Fritsch, 2011).

Special needs children are particularly challenged in today's educational environment. Changes in special education policy has eroded decades of necessary protections for special needs students, leading to increases in suspensions, expulsions and referrals to the juvenile justice system (The National Center on Education, Disability, and Juvenile Justice, 2003; National Council on Disability, 2002; Tulman, 2008).

Several studies have been conducted that attempt to measure the effect teachers have on the failure of at-risk youth in the classroom. Previous literature suggests that inclusion of special 
needs students in regular, non-special education classrooms has resulted in a more disruptive environment for learning (Bon et al., 2006; Boothby, 2002; Cook, 2004; Skiba and Sprague, 2008). Teacher frustration with the students and administrator's frustration with current legislation contribute to the school-to-prison pipeline metaphor (Bon et al., 2006; Boothby, 2002; Cook, 2004; Skiba and Sprague, 2008).

\section{Shortcomings of the Extant Literature}

This review of the literature addresses the effects that changes in special education law and public school policy have had on juvenile justice populations while exposing the need for further study into the school-to-prison pipeline metaphor. Many studies clearly identify a significant population of minority, poor and special needs students in the juvenile justice systems across the country ("Palm Beach," 2007; Laura 2010; Tuzzolo and Hewitt 2006; Wald and Losen 2003). Research is needed to determine whether current public education policy is significantly contributing to juvenile justice populations and if so, which variables are contributing to the referral of students by public schools to juvenile justice systems.

An important issue that is not addressed in the literature is identification of how or under what circumstances students have been removed from school, in particular, those students referred to juvenile justice agencies. The gap in research on the school-to-prison pipeline metaphor includes the lack of quantitative research that measures the actual disciplinary outcomes exercised by public schools. How many students did the school refer to juvenile justice? How many special education students did the school refer? Do variables exist within the demographic profile of the school that can be identified as additional predictors of juvenile justice referrals? These questions have not been addressed in the literature. My research attempts to answer the following research questions: 
1. Do some schools in eastern Oklahoma refer students to the Oklahoma Office of Juvenile Affairs (OJA) at greater rates than other schools in eastern Oklahoma?

2. If so, why?

3. Do some schools in eastern Oklahoma refer special needs students to the Oklahoma Office of Juvenile Affairs (OJA) at greater rates than other schools in eastern Oklahoma?

4. If so, why?

5. Do some schools in eastern Oklahoma refer a greater percentage of their population of special needs students to the OJA than other schools in eastern Oklahoma?

6. If so, why?

\section{Research Hypotheses}

Based on my review of previous research as well as in my theoretical understanding of the school-to-prison pipeline metaphor I propose nine hypotheses. These hypotheses are designed to answer the research questions:

Hypothesis 1. The higher the percentage of special needs students enrolled in the public school, the greater the percentage of students referred to the OJA.

Hypothesis 2. The higher the percentage of students receiving subsidized lunches in the public school, the greater the percentage of students referred to OJA.

Hypothesis 3. The higher the percentage of male students enrolled in the public school, the greater the percentage of students referred to the OJA.

Hypothesis 4. The higher the percentage of out-of-school suspensions by the public school, the greater the percentage of students referred by the school to the OJA. 
Hypothesis 5. The higher the percentage of African American students enrolled in the public school, the greater the percentage of students referred by the school to the OJA.

Hypothesis 6. The higher the percentage of Latino students enrolled in the public school, the greater the percentage of students referred by the school to the OJA.

Hypothesis 7. The higher the percentage of Native American students enrolled in the public school, the greater the percentage of students referred by the school to the OJA.

Hypothesis 8. Public schools with male principals will have greater percentages of students referred to the OJA than schools with female principals.

Hypothesis 9. Public schools with school resource officers (SRO's), will have greater percentages of students referred to the OJA than schools without SRO's.

\section{Conclusions}

Public schools, juvenile justice agencies, and the adult criminal justice system have essentially adopted the "get tough" ideology associated with the crime control model of justice. Public schools have adopted zero-tolerance disciplinary practices, juvenile justice waives significant numbers of juvenile offenders to adult court, and the criminal justice system in the U.S. incarcerates more people per capita than any other country in the world (Cole and Smith, 2010; Elrod and Ryder, 2005; Taylor and Fritsch, 2011). These policies have led many to believe that a school-to-prison pipeline exists in the U.S. in which public schools target at-risk populations for removal from school through suspensions, expulsions and referrals to juvenile justice agencies. Once these students populate the juvenile justice system they are vulnerable to further penetration ultimately entering into the adult criminal justice system (Leone et al., 2003; McIntosh, 2008; Tulman, 2008; Wald and Losen, 2003). 
Many systemic factors are related to the school-to-prison pipeline metaphor including zero-tolerance policies, increasing presence of law enforcement in public schools, changes in special education laws and the general attitude of public school administrators and teachers regarding the discipline of at-risk students. Poor students, minority students and special needs students are particularly vulnerable as evidenced by their overrepresentation among suspended, expelled and arrested students. These students represent a disturbing trend and a troubling profile of incarcerated youth in the U.S. (Beger, 2002; Teske and Huff, 2010; Tuzzolo and Hewitt, 2006; Wald and Losen, 2003).

The application of the "crime control model" of criminal justice towards public school children, through harsh disciplinary practices based on zero-tolerance, has had negative and unintended consequences on crime by increasing criminality. These policies continue even though little evidence supports a conclusion that "get tough" polices decrease negative behavior or criminal activity. On the other hand, the literature is saturated with evidence that pushing youth out of school through increased suspensions, expulsions and referrals to juvenile justice agencies increases the likelihood of future criminality (Hatt, 2011; Lynn, 2010; Tuzzolo and Hewitt, 2006; Wald and Losen, 2003). 


\section{Chapter 3 \\ Research Design}

The literature presented in chapter two describes an environment in which public education pushes at-risk students out of school and into the juvenile justice system and ultimately, the criminal justice system. The literature suggests that a school-to-prison pipeline exists. Although the indicators of a school-to-prison pipeline are established in the literature, we still do not know if some public schools are referring relatively large numbers of their students to juvenile justice. My research examines public schools in eastern Oklahoma to see if some refer greater percentages of (1) their students to the OJA, (2) their special needs students to the OJA, and (3) their special needs population to the OJA in eastern Oklahoma.

This chapter presents the research design in the following five sections: (1) research questions, (2) data collection, (3) dependent variables, (4) independent variables, hypotheses, and measurement of each concept/variable, and (5) method of data analysis.

\section{Research Questions}

This research design is a strategy with which to answer the following research questions:

1. Do some schools in eastern Oklahoma refer students to the Oklahoma Office of Juvenile Affairs (OJA) at greater rates than other schools in eastern Oklahoma?

2. If so, why?

3. Do some schools in eastern Oklahoma refer special needs students to the Oklahoma Office of Juvenile Affairs (OJA) at greater rates than other schools in eastern Oklahoma?

4. If so, why? 
5. Do some schools in eastern Oklahoma refer a greater percentage of their population of special needs students to the OJA than other schools in eastern Oklahoma?

6. If so, why?

\section{Data}

Population. The sample consists of 620 youth responding to a survey that was conducted within District 5 of the OJA. A map representing all the districts of OJA including District 5 is provided in Figure 3.1. The survey was conducted during the 2011 and 2012 school year between August 15, 2011 and June 15, 2012. The sample was drawn from District 5 of the OJA and consists of ten counties in eastern Oklahoma (Adair, Cherokee, Haskell, Leflore, McIntosh, Muskogee, Okfuskee, Okmulgee, Sequoyah, and Wagoner). Within the OJA District 5, there are 154 public schools, that include grade six or higher. The study examines 62 prekindergarten through eighth grade schools, ${ }^{9} 30$ middle schools and 62 high schools. Elementary schools without seventh and eighth grade students were excluded from the study. Charter schools, alternative schools, and private schools were also excluded from the study. Each school in the study was identified using OJA reference coding and the Oklahoma Department of Education (DOE) coding.

\footnotetext{
${ }^{9}$ For the purposes of this study, pre-kindergarten through the $5^{\text {th }}$ grade have been removed from the total population for all pre-k through $8^{\text {th }}$ grade schools.
} 


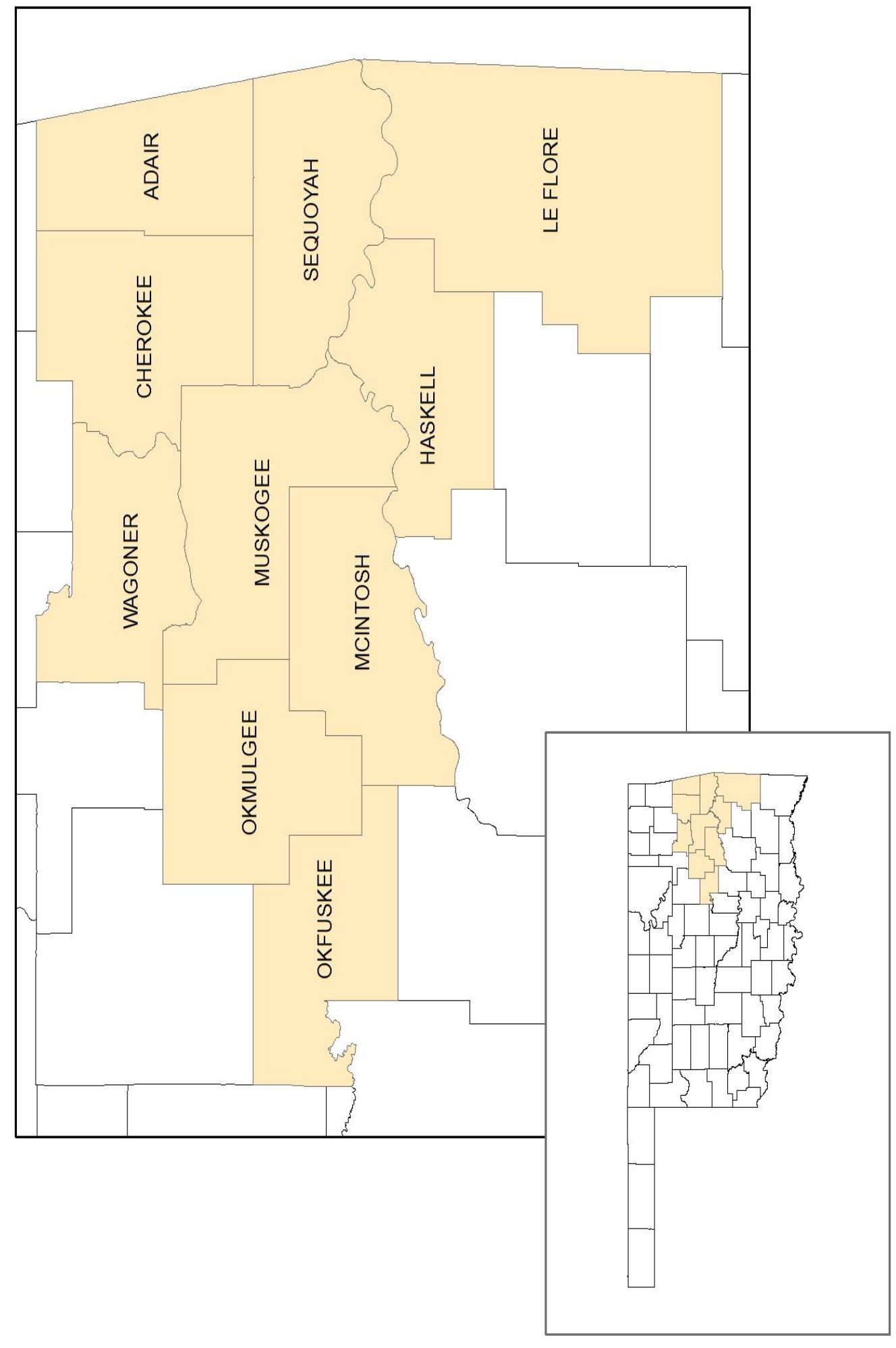

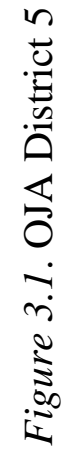


Data collection from the OJA. During the study period, each intake worker for the OJA within the District 5 was instructed by the OJA District Supervisor to conduct a survey during the intake process. The survey instrument was developed by the OJA (the technical support staff in the OJA state office) located in Oklahoma City, Oklahoma. The survey instrument was designed in an effort to collect unique data and minimize redundancy during the intake process. The survey instrument was electronically added to the juvenile online tracking system (JOLTS) intake fact sheet and the computerized management system (CMS). The survey instrument required intake workers assigned to each of the ten counties within District 5 of the OJA to ask every youth referred to the OJA the following three questions: (1) have you ever had an IEP, (2) do you currently have an IEP, and (3) did the incident resulting in your referral to the OJA happen at school, on school property, or during a school function? Validity protocols were conducted to ensure proper IEP responses were entered into the survey through parental confirmation of the responses during the intake process and cross referencing the responses with the Youth Level of Services Inventory (YLSI) conducted on all adjudicated youth as part of the mandatory predisposition study. Incident location responses were cross-referenced with referral information from police reports.

Training was provided to the intake workers at their district meeting 30 days prior to the study. The intake workers were trained by the researcher and district supervisor. Training included technical direction, cross-referencing and validity concerns, policy implications, and significance of the research. Administration of the survey was monitored monthly by the district supervisor and assistant district supervisors (immediate supervisors of the intake workers) throughout the district. Follow-up with the survey data collection was further monitored by the researcher through communication with the district supervisor. Each county was monitored 
continually by the district supervisor to ensure that each of the referrals to the OJA had a corresponding survey. The survey data was compiled by the OJA technical support staff in Oklahoma City and provided to the researcher. The survey data was codified using the OJA reference codes indicating the school attended at the time of the referral. The researcher manually entered all data into an excel spreadsheet cross-referencing the data with the DOE coding. The data was imported from Excel into SPSS for analysis.

Measuring the number of youth referred to the OJA provides critical data and is at the core of discovery regarding the school-to-prison process. District 5 of the OJA consists of a cross section of rural and urban youth residing in eastern Oklahoma. By stressing the importance of the survey and providing minimal electronic data collection it is believed that response rates would be high and missing data would be minimized. The survey data has been retrospectively reviewed with the actual intake numbers to establish error rates and/or missing survey data.

Data collection from the Oklahoma Department of Education. A public information request was provided to the Oklahoma Department of Education (DOE) which included the Institutional Review Board approval from the University of Arkansas (see Appendix A) and Northeastern State University (see Appendix B). The following administrative data on students attending each school during the 2011-2012 academic calendar year was requested and received from the DOE for each school within the OJA District 5:

- Total enrollment in the school (including enrollment by grade) ${ }^{10}$

- Designation of the school (elementary, pk-8, middle, high) ${ }^{11}$

\footnotetext{
${ }^{10}$ Collected from the Oklahoma Department of Education, Department of Ed School Directory dated April 11, 2012.

${ }^{11}$ Collected from the Oklahoma Department of Education: Department of Ed School Directory dated April 11, 2012
} 
- Total enrollment of special needs students in the school ${ }^{12}$

- Total number of students in the school receiving a free or subsidized lunch ${ }^{13}$

- Total enrollment of male students in the school ${ }^{14}$

- Total number of out-of-school suspensions by the school ${ }^{15}$

- Total enrollment of African American students in the school ${ }^{16}$

- Total enrollment of Latino students in the school ${ }^{17}$

- Total enrollment of Native American students in the school ${ }^{18}$

- Gender of principal ${ }^{19}$

- Presence/absence of a school resource officer ${ }^{20}$

${ }^{12}$ Collected by the Oklahoma Department of Education Special Education Services: 2011-2012 Students on IEP, request dated May 2, 2013.

${ }^{13}$ Collected by the Oklahoma Department of Education: 2011-2012 Students Receiving Subsidized/Free Lunch, request dated May 2, 2013.

${ }^{14}$ Collected by Janet Barresi, State Superintendent of Public Instruction, State Department of Education: Application for Accreditation dated Oct. 3, 2011 Membership Public Schools only. ${ }^{15}$ Collected by the Oklahoma Department of Education Special Education Services: 2011-2012 Suspensions and Expulsions, request dated May 2, 2013. There was a small amount of expulsions omitted from the data set.

${ }^{16}$ Collected by Janet Barresi, State Superintendent of Public Instruction, the State of Oklahoma Department of Education: Application for Accreditation dated Oct. 3, 2011 Membership Public Schools only.

${ }^{17}$ Collected by Janet Barresi, State Superintendent of Public Instruction, the State of Oklahoma Department of Education: Application for Accreditation dated Oct. 3, 2011 Membership Public Schools only.

${ }^{18}$ Collected by Janet Barresi, State Superintendent of Public Instruction, the State Department of Education: Application for Accreditation dated Oct. 3, 2011 Membership Public Schools only. ${ }^{19}$ Collected from the Oklahoma Department of Education: Department of Ed School Directory dated April 11, 2012

20 The presence of a school resource officer at the school was verified by the OJA intake worker for each respective county and the school district. 
The schools have been codified by using the Oklahoma Department of Education site codes and the OJA reference codes. Individual schools have further been codified as either elementary ${ }^{21}$, Pre-K $-8^{\text {th }}$ grade, middle school, or high school.

\section{The Dependent Variables}

My first dependent variable $\left(\mathrm{Y}_{1}\right)$ is the number of students referred by the public school to the OJA divided by the number of students enrolled in the public school during the 2011 and 2012 school year (between 06/15/2011 and 08/15/2012).

My second dependent variable $\left(\mathrm{Y}_{2}\right)$ is the number of special needs students referred by the public school to the OJA divided by the number of students enrolled in the public school during the 2011 and 2012 school year (between 06/15/2011 and 08/15/2012).

My third dependent variable $\left(\mathrm{Y}_{3}\right)$ is the number of special needs students referred by the public school to the OJA divided by the number of special needs students enrolled in the public school during the 2011 and 2012 school year (between 06/15/2011 and 08/15/2012).

\section{Independent Variables, Hypotheses and Measurement}

Independent Variable $1\left(\mathrm{X}_{1}\right)$. My first independent variable $\left(\mathrm{X}_{1}\right)$ is the percentage of special needs students enrolled in the public school in eastern Oklahoma.

Hypothesis $1\left(\boldsymbol{H}_{1}\right)$. The higher the percentage of special needs students enrolled in the public school, the higher the percentage of students referred to the OJA. This hypothesis uses Y1 as the dependent variable; however, this expectation also applies to the hypotheses using Y2 and Y3 as dependent variables. Thus, for each independent variable, X1 through X9, the expectation for the relationship between $\mathrm{X}$ and $\mathrm{Y} 1$ is the same as the expectation for $\mathrm{X}$ and $\mathrm{Y} 2$ and $\mathrm{X}$ and

21 The elementary schools were omitted from the study after they were identified. 
Y3. Due to space limitations (and to minimize redundancy), I do not write separate hypotheses for Y2 and Y3.

Measurement $\left(X_{1}\right)$. The independent variable $\left(\mathrm{X}_{1}\right)$ is measured as follows: The number of special needs students enrolled in the public school during the 2011 - 2012 school year (between 06/15/2011 and 08/15/2012) divided by the number of students enrolled in the school.

Independent Variable-2 $\left(\mathbf{X}_{2}\right)$. My second independent variable $\left(\mathrm{X}_{2}\right)$ is the percentage of students receiving free and reduced lunch enrolled in the public school in eastern Oklahoma.

Hypothesis $2\left(\boldsymbol{H}_{2}\right)$. The higher the percentage of students receiving subsidized lunches in the public school, the higher the percentage of students referred to OJA.

Measurement $2\left(X_{2}\right)$. The independent variable $\left(\mathrm{X}_{2}\right)$ is measured as follows: The number of students receiving free and reduced lunches enrolled in the public school during the 2011 2012 school year (between 06/15/2011 and 08/15/2012) divided by the number of students enrolled in the public school.

Independent Variable-3 (X). My third independent variable is the percentage of male students enrolled in the public school in eastern Oklahoma.

Hypothesis $3\left(\boldsymbol{H}_{3}\right)$. The higher the percentage of male students enrolled in the public school, the greater the percentage of students referred to the OJA.

Measurement $3\left(X_{3}\right)$. The independent variable $\left(\mathrm{X}_{3}\right)$ is measured as follows: The number of male students enrolled in the public school during the 2011 - 2012 school year (between 06/15/2011 and 08/15/2012) divided by the number of students enrolled in the public school.

Independent Variable-4 $\left(\mathbf{X}_{4}\right)$. The fourth independent variable $\left(\mathrm{X}_{4}\right)$ is the percentage of out-of-school suspensions by the public school in eastern Oklahoma. 
Hypothesis $4\left(\mathrm{H}_{4}\right)$. The higher the percentage of out-of-school suspensions by the public school, the greater the percentage of students referred by the school to the OJA.

Measurement $4\left(\mathbf{X}_{4}\right)$. The independent variable $\left(\mathrm{X}_{4}\right)$ is measured as follows: the number of out-of-school suspensions by the public school during the 2011 - 2012 school year (between 06/15/2011 and 08/15/2012) divided by the number of students enrolled in the public school.

Independent Variable-5 $\left(\mathbf{X}_{5}\right)$. My fifth independent variable $\left(\mathrm{X}_{5}\right)$ is the percentage of African American students enrolled in the public school in eastern Oklahoma.

Hypothesis $5\left(\boldsymbol{H}_{5}\right)$. The higher the percentage of African American students enrolled in the public school, the higher the percentage of students referred by the school to the OJA.

Measurement $\left(\mathrm{X}_{5}\right)$. The independent variable $\left(\mathrm{X}_{5}\right)$ is measured as follows: The number of African American students enrolled in the public school during the 2011 - 2012 school year (between 06/15/2011 and 08/15/2012) divided by the number of students enrolled in the public school.

Independent Variable-6 $\left(\mathbf{X}_{6}\right)$. My sixth independent variable $\left(\mathrm{X}_{6}\right)$ is the percentage of Latino students enrolled in the public school in eastern Oklahoma.

Hypothesis $\mathbf{6}\left(\boldsymbol{H}_{6}\right)$. The higher the percentage of Latino students enrolled in the public school, the higher the percentage of students referred by the school to the OJA.

Measurement $\left(\mathrm{X}_{6}\right)$. The independent variable $\left(\mathrm{X}_{6}\right)$ is measured as follows: The number of Latino students enrolled in the public school during the 2011 - 2012 school year (between 06/15/2011 and 08/15/2012) divided by the number of students enrolled in the public school.

Independent Variable-7 $\left(\mathbf{X}_{7}\right)$. My seventh independent variable $\left(\mathrm{X}_{7}\right)$ is the percentage of Native American students enrolled in the public school in eastern Oklahoma. 
Hypothesis $7\left(\mathrm{H}_{7}\right)$. The higher the percentage of Native American students enrolled in the public school, the higher the percentage of students referred by the school to the OJA.

Measurement $7\left(X_{7}\right)$. The independent variable $\left(X_{7}\right)$ is measured as follows: The number of Native American students enrolled in the public school during the 2011 - 2012 school year (between 06/15/2011 and 08/15/2012) divided by the number of students enrolled in the public school.

Independent Variable-8 $\left(\mathbf{X}_{8}\right)$. My eighth independent variable $\left(\mathrm{X}_{8}\right)$ is the presence of a male principal in the public school in eastern Oklahoma.

Hypothesis $8\left(H_{8}\right)$. Public schools with male principals will have higher percentages of students referred to the OJA than schools with female principals.

Measurement $\left(\mathrm{X}_{8}\right)$. The independent variable $\left(\mathrm{X}_{8}\right)$ is measured as follows: male principal is coded as 1 and female principal coded as 0 (during the 2011 - 2012 school year (between 06/15/2011 and 08/15/2012).

Independent Variable-9 ( $\left.\mathrm{X}_{9}\right)$. My ninth independent variable $\left(\mathrm{X}_{9}\right)$ is the presence of a school resource officer (SRO) in the public school in eastern Oklahoma.

Hypothesis $9\left(H_{9}\right)$. Schools with resource officers (SRO), will have higher percentages of students referred to the OJA than schools without SROs.

Measurement $\left(\mathrm{X}_{9}\right)$. The independent variable $\left(\mathrm{X}_{9}\right)$ is measured as follows: the presence of a school resource officer in the public school during the 2011 - 2012 school year (between 06/15/2011 and 08/15/2012) is coded as 1 ; the absence of an SRO is coded as zero.

\section{Methods of Data Analysis}

Descriptive statistics were generated to examine measures of central tendency and dispersion for the dependent and independent variables. The analysis includes the minimum and 
maximum values, mean values, median, and standard deviations for each dependent and independent variable. Univariate data analysis is used to measure frequencies. This information is presented in the next chapter in Tables 4.1 and 4.2.

Ordinary least squares regression analysis is used to test each hypothesis $\left(\mathrm{H}_{1}\right.$ through $\left.\mathrm{H}_{9}\right)$ for all three dependent variables $\left(\mathrm{Y}_{1}\right.$ through $\left.\mathrm{Y}_{3}\right)$. For each of the three dependent variables there are two models. The first model (Model 1) includes each of the nine (9) independent variables listed. The second model (Model 2), omits the first independent variable, the percentage of special needs students enrolled in the public school, and includes the remaining eight (8) independent variables. This information is presented in the next chapter in Tables 4.3, 4.4, and 4.5. Standard multiple regression is used because it "enables the prediction of one variable on the basis of the value of others" (Hagan, 2014, p. 54). Removal of the first independent variable in the second model, the percentage of special needs students enrolled in the public school, controls for cultural differences in public schools with larger populations of special needs students which may exhibit higher behavioral problems in the school resulting in more referrals. Collinearity diagnostics were examined to make sure there is no violation of the assumption of no multicollinearity among the independent variables. Finally, individual schools were ranked in descending order based on the percentage of referrals for each of the dependent variables. This information is reported in Tables 4.6., 4.7, and 4.8. 


\section{Chapter 4}

\section{Empirical Results}

\section{Introduction}

The chapter begins with a demographic profile of the region of Oklahoma included in the research. Demographics include geographic area, ethnicity, poverty, and education. A description of the sample includes a breakdown of the criteria used to determine which public schools were appropriate for the study and percentages for each of the different school designations used by the Oklahoma Department of Education. Sources of referrals to the OJA including the number of referrals are also discussed.

Descriptive statistics are examined for each of the dependent and independent variables. Analysis of the descriptive statistics includes the minimum and maximum percentages and the mean score, median, range, and standard deviation.

In order to determine the relationship between each independent variable and the dependent variables, ordinary least squares regression is used. Unstandardized betas are reviewed to determine the size of the effects on the dependent variables. Standardized betas are not presented in the tables, but are discussed in order to rank the relative effect of each of the significant independent variables on the dependent variables. Each of the three tables (Table 4.3, Table 4.4, and Table 4.5) includes two models. Model 1 measures the relative contribution of nine independent variables including the percentage of special needs students enrolled in the school. The second model, Model 2, omits the percentage of special needs students enrolled in the school as an independent variable.

Finally, the top five percent of public schools referring students to the OJA are reported by name in Tables 4.6, 4.7, and 4.8. 


\section{Description of the Sample}

Demographic profile of District 5 of the OJA. There are 10 counties within the boundaries of District 5 of the OJA. District 5 of the OJA is centrally located on the eastern border of the State of Oklahoma. The biggest portion of the region is rural with three mediumsized cities with populations under 40,000. According to the 2010 census, Muskogee, Oklahoma has the largest population in the region with 39,223 residents. This portion of the State of Oklahoma has a large Native American population. Included within the district are the Cherokee, Choctaw, and Creek Nations of Oklahoma. Cherokee county has one of the state's highest poverty rates at 26 percent (Tahlequah Daily Press, 2012). The National Center for Children in Poverty's 2009 annual report detailed poverty levels in Oklahoma. The report indicates that 33 percent of young American Indian Children, 51 percent of young Black children, 38 percent of young Hispanic children, and 16 percent of young white children in Oklahoma are members of a family living below the poverty line (Tulsa World, 2012).

Public schools in District 5 of the OJA. Of the 213 public schools reported by the Oklahoma Department of Education within District 5 of the OJA, $154(\mathrm{~N}=154)$ schools were identified as appropriate for the study. The sample consists of 40 percent pre-kindergarten through eighth grade schools, ${ }^{22} 20$ percent middle schools and 40 percent high schools. Elementary schools without seventh and eighth grade students were excluded from the study. Charter schools, alternative schools, and private schools were also excluded from the study.

During the 2011 and 2012 school year, 620 students were referred from many sources to the District 5 of the OJA. Sources of referrals to the OJA include, but are not limited to, law

\footnotetext{
${ }^{22}$ For the purposes of this study, pre-kindergarten through the $5^{\text {th }}$ grade have been removed from the total population for all pre-k through $8^{\text {th }}$ grade schools.
} 
enforcement, parents, social workers, counselors, victims of criminal activities perpetrated by juveniles, concerned citizens, and public schools. 197 students were referred to the OJA by the public schools in which they were enrolled. This accounts for approximately 32 percent of the referral total. Of the 197 students referred by public schools to the OJA, 93 were classified as special needs students (have had or are currently on an IEP). Special needs students represent approximately 47 percent of the students referred by the public school.

\section{Descriptive Statistics}

Description of the dependent variables. The descriptive statistics for the dependent variables are presented in Table 4.1. The first dependent variable, the percentage of referrals to the OJA by the public school, indicates a percentage of referrals (Mean $=.50$, Standard Deviation $=1.0$ ) with a minimum of zero (0) percent and a maximum of six (6) percent. The second dependent variable, the percentage of special needs students referred to the OJA by the public school, indicates a percentage of referrals (Mean=.20, Standard Deviation=.70) with a minimum of zero (0) percent and a maximum of six (6) percent. The third dependent variable, the percentage of the schools special needs students referred to the OJA by the public school, indicates a percentage of referrals (Mean $=.70$, Standard Deviation $=1.6)$ with a minimum of zero (0) and a maximum of eight (8) percent. 
Table 4.1

Descriptive Statistics for Dependent Variables

\begin{tabular}{lccccc} 
& $\begin{array}{c}\text { Number of } \\
\text { Schools }\end{array}$ & Range & Mean & SD & Median \\
\hline $\begin{array}{l}\text { Percentage of students referred } \\
\text { to the OJA }\end{array}$ & 154 & $0-5.88$ & .4959 & 1.04231 & .0000 \\
$\begin{array}{l}\text { Percentage of special needs students } \\
\text { referred to the OJA }\end{array}$ & 154 & $0-5.88$ & .2173 & .70981 & .0000 \\
$\begin{array}{l}\text { Percentage of the school's special } \\
\text { needs } \\
\text { students referred to the OJA }\end{array}$ & 154 & $0-8.19$ & .6775 & 1.59882 & .0000 \\
\hline
\end{tabular}

Description of the independent variables. The descriptive statistics for the continuous level independent variables are presented in Table 4.2. The first independent variable, the percentage of special needs students enrolled in the public school, shows an average enrollment of 24 percent $($ Mean=24) with a variability of 10.5 percent $($ Standard Deviation $=10.5)$. The enrollment of special needs students in the public schools ranges from a minimum of zero (0) to a maximum of 74 percent. The second independent variable, the percentage of students receiving a free or subsidized lunch, shows an average of 73 percent $($ Mean $=73)$ with a variability of 15 percent $($ Standard Deviation $=15)$. The percentage of students enrolled in the school receiving a free of subsidized lunch ranges from a minimum of 5.5 percent to a maximum of 100 percent. Seven schools within the district reported 100 percent of their student enrollment as receiving a free or subsidized lunch. This is empirical evidence that the poverty levels within the geographic boundaries of the district are well above the national average. The third independent variable, the percentage of male students enrolled in the public school, shows that slightly more than half of the school enrollment is male. The average male enrollment is 52 percent $($ Mean $=52)$ with a 
variability of seven $(7)$ percent (Standard Deviation $=7$ ). The percentage of male students enrolled in the school ranges from a minimum of 34 percent to a maximum of 78 percent. The fourth independent variable, the percentage of out-of-school suspensions per student enrollment, shows an average of .45 percent $($ Mean $=.45)$ with a variability of one (1) percent (Standard Deviation $=1$ ). The number of out-of-school suspensions by the school ranges from a minimum of zero (0) to a maximum of 13 percent.

Table 4.2

Descriptive Statistics for Continuous Level Independent Variables

\begin{tabular}{lccccc} 
& $\begin{array}{c}\text { Number } \\
\text { of } \\
\text { Schools }\end{array}$ & Range & Mean & SD & Median \\
& 154 & $0-74.12$ & 24.15 & 10.49 & 22.94 \\
$\begin{array}{l}\text { Percentage of special needs students } \\
\text { enrolled }\end{array}$ & 154 & $5.5-100$ & 73.33 & 15.20 & 74.47 \\
$\begin{array}{l}\text { Percentage of students receiving a } \\
\text { Free or subsidized lunch }\end{array}$ & 154 & $34-77.78$ & 51.99 & 6.67 & 52.06 \\
$\begin{array}{l}\text { Percentage of male students } \\
\text { enrolled }\end{array}$ & 154 & $0-12.94$ & .45 & 1.46 & .00 \\
$\begin{array}{l}\text { Percentage of out-of-school } \\
\text { Suspensions per population }\end{array}$ & & & & & \\
$\begin{array}{l}\text { Percentage of African American } \\
\text { students enrolled }\end{array}$ & 154 & $0-34.65$ & 3.99 & 6.44 & 1.77 \\
$\begin{array}{l}\text { Percentage of Latino students } \\
\text { enrolled }\end{array}$ & 154 & $0-32.08$ & 3.47 & 4.45 & 2.70 \\
$\begin{array}{l}\text { Percentage of Native American } \\
\text { students enrolled }\end{array}$ & 154 & $1.09-100$ & 41.86 & 20.07 & 40 \\
\hline
\end{tabular}

Independent variables: minority enrollment. The fifth independent variable is the percentage of African American students enrolled in the public school. The average African 
American enrollment is four (4) percent (Mean $=4)$ with a variability of six (6) percent (Standard Deviation =6). The percentage of African American students enrolled in the school ranges from a minimum of 0 percent to a maximum of 35 percent. The sixth independent variable is the percentage of Latino students enrolled in the public school. The average Latino enrollment is three 3 percent with a variability of 4 percent $($ Standard Deviation $=4)$. The percentage of Latino students enrolled in the school ranges from a minimum of 0 percent to a maximum of 32 percent. The seventh independent variable is the percentage of Native American students enrolled in the school. The average enrollment is 42 percent, and the standard deviation is 20. The percentage of Native American students enrolled in the school ranges from a minimum of 1 percent to a maximum of 100 percent. Eastern Oklahoma has a large concentration of Native American students and the geographic area of the study includes portions of the Cherokee, Choctaw and Creek Nations of Oklahoma.

Dichotomous independent variables. The eighth independent variable, a dichotomous variable, is the presence of a male principal at the school. 111 schools (72 percent) reported having a male principal while 43 schools ( 28 percent) reported having a female principal. The ninth independent variable, a dichotomous variable, is the presence of a school resource officer at the school. 57 (37 percent) of the schools reported having at least one school resource officer while 97 (63 percent) reported not having a school resource officer.

\section{Multiple Regression Results}

Percentage of students referred to the OJA by the public school. Table 4.3 reports the results of the multiple regression models with the total number of students referred to the OJA by the public school divided by the total enrollment of the school as the dependent variable. Model 1 includes an analysis of each of the nine independent variables. The table reports 
unstandardized betas, t-scores, and significance levels. Three independent variables are significant in the predicted direction. The parameter estimates indicate that public schools with greater percentages of special needs students are more likely to refer greater percentages of students to the OJA. The unstandardized estimate indicates that for every one percentage point increase in the enrollment of special needs students, referrals to the OJA will increase by .015 percentage points. In Model 1, the percentage of special needs students enrolled in the school has the third greatest effect on the dependent variable (standardized Beta $=.150$ ).

The parameter estimate indicates that public schools with greater percentages of male students are more likely to refer greater percentages of students to the OJA. The unstandardized estimate indicates that for every one percentage point increase in the enrollment of male students, referrals to the OJA will increase by .03 percentage points. In Model 1, the percentage of male students enrolled in the school has the second greatest effect on the dependent variable (standardized Beta $=.191)$.

The parameter estimate indicates public schools with greater percentages of African American students are more likely to refer greater percentages of students to the OJA (Sig. = .004). The unstandardized estimate indicates that for every one percentage point increase in the enrollment of African American students, referrals to the OJA will increase by .037 percentage points. In Model 1, the percentage of African American students enrolled in the school has the greatest effect on the dependent variable (standardized Beta $=.229$ ).

The regression model indicates that no relationship exists between the percentages referred to the OJA and the following independent variables: (1) the percentage of students receiving a free or subsidized lunch enrolled in the school; (2) the percentage of out-of-school suspensions by the school; (3) the percentage of Latino students enrolled in the school; (4) the 
percentage of Native American students enrolled in the school; (5) the presence of a male principal in the school; and (6) the presence of a school resource officer at the school.

Table 4.3

Multiple Regression Results for Variables Associated with the Percentage of Students Referred to the OJA

Model $1 \%$ of School Referrals

\begin{tabular}{|c|c|c|c|c|c|c|}
\hline Variable & $\begin{array}{c}\text { standard } \\
\text { beta }\end{array}$ & $\mathrm{t}$ & Sig. & $\begin{array}{c}\text { standard } \\
\text { beta }\end{array}$ & $\mathrm{t}$ & Sig. \\
\hline$\%$ special needs & .015 & 1.513 & $.066^{*}$ & -- & -- & -- \\
\hline$\%$ free/sub lunch & .004 & .725 & .235 & .008 & 1.405 & $.081 *$ \\
\hline$\%$ male students & .030 & 2.291 & $.011 * *$ & .030 & 2.292 & $.011 * *$ \\
\hline$\%$ OSS & -.044 & -.706 & .481 & -.011 & -.183 & .363 \\
\hline$\%$ African American & .037 & 2.640 & $.004 * * *$ & .036 & 2.542 & $.006 * * *$ \\
\hline$\%$ Latino & .016 & .791 & .215 & .011 & .558 & .289 \\
\hline$\%$ Native American & .000 & -.106 & .916 & .001 & .194 & .423 \\
\hline Principal gender & .129 & .690 & .246 & .183 & .991 & .161 \\
\hline SRO presence & -.103 & -.548 & .585 & -.132 & -.706 & .481 \\
\hline Constant & -1.960 & -2.619 & $.010^{* * *}$ & -1.951 & -2.595 & $.010 * * *$ \\
\hline Number of schools & & 154 & & & 154 & \\
\hline $\mathrm{R}^{2}$ & & .114 & & & .100 & \\
\hline
\end{tabular}

Model 2 w/o the \% of special needs enrolled

Note: The dependent variable is the percentage of students referred to the OJA by public school divided by the total enrollment in the school. $* \mathrm{p}<.10 ; * * \mathrm{p}<.05 ; * * * \mathrm{p}<.01$.

The second regression model (Model 2) in Table 4.3 omits the percentage of special needs students enrolled in the school as a variable. The results for Model 2 indicate that public 
schools with greater percentages of students receiving a free or subsidized lunch are more likely to refer greater percentages of students to the OJA, but this relationship is only significant at $\mathrm{p} \leq .10$. The unstandardized estimate indicates that for every one percentage point increase in the enrollment of students receiving a free or subsidized lunch, referrals to the OJA will increase by .008 percentage points. In Model 2, the percentage of students receiving a free or subsidized lunch enrolled in the school has the third greatest effect on the dependent variable (standardized Beta $=.118)$.

The parameter estimate indicates that public schools with greater percentages of male students are more likely to refer greater percentages of students to the OJA $(\mathrm{Sig} .=.011)$. The unstandardized estimate indicates that for every one percentage point increase in the enrollment of male students, referrals to the OJA will increase by .03 percentage points. In Model 2, the percentage of male students enrolled in the school has the second greatest effect on the dependent variable ( standardized Beta $=.192$ ).

The parameter estimate for African American students indicates that public schools with greater percentages of African American students are more likely to refer greater percentages of students to the OJA $(\mathrm{Sig} .=.006)$. For every one percentage point increase in the enrollment of African American students, referrals to the OJA will increase by almost .04 percentage points. The percentage of African American students enrolled in the school has the highest standardized beta value.

Model 2 indicates that no relationship exists between the percentages referred to the OJA and the following independent variables: (1) the percentage of out-of-school suspensions by the school; (2) the percentage of Latino students enrolled in the school; (3) the percentage of Native 
American student enrolled in the school; (4) the presence of a male principal in the school; and (5) the presence of a school resource officer at the school.

Correlations for independent variables. The independent variables do not indicate multi-collinearity. The collinearity diagnostics from the correlation matrix indicate no violation of the multi-collinearity assumption using the standard cut-off points. The tolerance (1-R squared) for each of the independent variables is greater than .10 and the variance inflation factor (VIF) for each of the independent variables is less than 10 (Healey, 2009).

Percentage of special needs students referred to the OJA by the public school. Table 4.4 reports the results of the multiple regression models based on the following dependent variable: the total number of special needs students referred to the OJA by public schools divided by the total enrollment of the school. Three variables in the model are significant. Public schools with greater percentages of special needs students are more likely to refer greater percentages of special needs students to the OJA $($ Sig. $=.008)$. The unstandardized estimate indicates that for every one percentage point increase in the enrollment of special needs students, referrals to the OJA of special needs students will increase by .016 percentage points. In Model 1, the percentage of special needs students enrolled in the school has the third greatest effect on the dependent variable (standardized Beta $=.230)$. 
Table 4.4

Multiple Regression Results for Variables Associated with the Percentage of Special Needs Students Referred to the OJA

Model $1 \%$ of Special Need school referrals

unstandardized
Model 2 w/o the \% of special needs

\begin{tabular}{|c|c|c|c|c|c|c|}
\hline Variable & $\begin{array}{l}\text { andardi } \\
\text { beta }\end{array}$ & $\mathrm{t}$ & Sig. & $\begin{array}{c}\text { tandard } \\
\text { beta }\end{array}$ & $\mathrm{t}$ & Sig. \\
\hline$\%$ special needs & .016 & 2.423 & $.008 * * *$ & -- & -- & -- \\
\hline$\%$ free/sub lunch & -.003 & -.86 & .391 & .000 & .070 & .472 \\
\hline$\%$ male students & .025 & 2.892 & $.002 * * *$ & .025 & 2.862 & $.002 * * *$ \\
\hline$\%$ OSS & -.049 & -1.186 & .237 & -.014 & -.347 & .729 \\
\hline$\%$ African American & .038 & 4.104 & $.000 * * *$ & .036 & 3.900 & $.000 * * *$ \\
\hline$\%$ Latino & .013 & .974 & .166 & .008 & .591 & .278 \\
\hline$\%$ Native American & .003 & 1.136 & .129 & .005 & 1.616 & $.054 *$ \\
\hline Principal gender & .056 & .460 & .323 & .113 & .923 & .179 \\
\hline SRO presence & -.083 & -.677 & .500 & -.114 & -.919 & .360 \\
\hline Constant & -1.513 & -3.090 & $.002 * * *$ & -1.503 & -3.019 & $.003 * * *$ \\
\hline Number of schools & \multicolumn{3}{|c|}{154} & \multicolumn{3}{|c|}{154} \\
\hline $\mathrm{R}^{2}$ & \multicolumn{3}{|c|}{.183} & \multicolumn{3}{|c|}{.149} \\
\hline
\end{tabular}

Note: The dependent variable is the percentage of special needs students referred to the OJA by public schools divided by the total enrollment in the school. * $\mathrm{p}<.10 ; * * \mathrm{p}<.05 ; * * * \mathrm{p}<.01$.

Public schools with greater percentages of male students are more likely to refer greater percentages of special needs students to the OJA $($ Sig. $=.002)$. The unstandardized estimate indicates that for every one percentage point increase in the enrollment of male students, referrals of special needs students to the OJA will increase by .025 percentage points. In Model 
1 , the percentage of male students enrolled in the school has the second greatest effect on the dependent variable (standardized Beta $=.232$ ).

Schools with greater percentages of African American students are more likely to refer greater percentages of special needs students to the OJA $(\mathrm{Sig} .=.000)$. The model indicates that for every one percentage point increase in the enrollment of African American students, referrals of special needs students to the OJA will increase by .038 percentage points. The percentage of African American students enrolled in the school has the greatest effect on the dependent variable (standardized Beta $=.343$ ).

Model 1 indicates that no relationship exists between the percentages of special needs students referred to the OJA and the following independent variables: (1) the percentage of students receiving a free or subsidized lunch enrolled in the school; (2) the percentage of out-ofschool suspensions by the school; (3) the percentage of Latino students enrolled in the school; (4) the percentage of Native American student enrolled in the school; (5) the presence of a male principal in the school; and (6) the presence of a school resource officer at the school.

The second regression model (Model 2) in Table 4.4 omits the percentage of special needs students enrolled in the school as a variable. The results for Model 2 indicate that public schools with greater percentages of Native American students are more likely to refer greater percentages of special needs students to the OJA, but this relationship is only significant at $\mathrm{p} \leq .10$. The unstandardized estimate indicates that for every one percentage point increase in Native American students enrolled in the public school, referrals of special needs students to the OJA will increase by .005 percentage points. In Model 2, the percentage of Native American students enrolled in the school has the third greatest effect on the dependent variable (standardized Beta $=.118)$. 
Public schools with greater percentages of male students are more likely to refer greater percentages of special needs students to the OJA (Sig. $=.002$ ). The model indicates that for every one percentage point increase in the enrollment of male students, referrals of special needs students to the OJA will increase by .036 percentage points. In Model 2, the percentage of male students enrolled in the school has the second greatest effect on the dependent variable $($ standardized Beta $=.233)$.

Public schools with greater percentages of African American students are more likely to refer greater percentages of special needs students to the OJA $(\mathrm{Sig} .=.000)$. For every one percentage point increase in the enrollment of African American students, referrals of special needs students to the OJA will increase by .036 percentage points. The percentage of African American students enrolled in the school has the highest standardized Beta value (=.330).

Model 2 indicates that no relationship exists between the percentages of special needs students referred to the OJA and the following independent variables: (1) the percentage of students receiving a free or subsidized lunch; (2) the percentage of out-of-school suspensions by the school; (3) the percentage of Latino students enrolled in the school; (4) the presence of a male principal in the school; and (5) the presence of a school resource officer at the school.

Percentage of a school's special needs population referred to the OJA. Table 4.5 reports the results of the multiple regression models with the total number of special needs students referred by the public school divided by the total population of special needs students enrolled in the school as the dependent variable. Two variables are significant: Public schools with greater percentages of male students are more likely to refer greater percentages of special needs students to the OJA $(\mathrm{Sig} .=.043)$. The unstandardized estimate indicates that for every one percentage point increase in the enrollment of male students, referrals of their special needs 
students to the OJA will increase by .034 percentage points. In Model 1 the percentage of male students enrolled in the school has the second greatest effect on the dependent variable $($ standardized Beta $=.144)$.

Table 4.5

Multiple Regression Results for Variables Associated with the Percentage of the Schools Special Needs Population Referred to the OJA

Model $1 \%$ of Schools Special Needs $\quad \begin{aligned} & \text { Model } 2 \text { w/o the \% of special } \\ & \text { Population referred }\end{aligned}$
needs

\begin{tabular}{|c|c|c|c|c|c|c|}
\hline Variable & $\begin{array}{l}\text { andardized } \\
\text { beta }\end{array}$ & $\mathrm{t}$ & Sig. & $\begin{array}{l}\text { andardi } \\
\text { beta }\end{array}$ & $\mathrm{t}$ & Sig. \\
\hline$\%$ special needs & -.013 & -.861 & .391 & -- & -- & -- \\
\hline$\%$ free/sub lunch & .000 & -.036 & .971 & -.003 & -.396 & .693 \\
\hline$\%$ male students & .034 & 1.728 & $.043 * *$ & .034 & 1.723 & $.043 * *$ \\
\hline$\%$ OSS & .080 & .836 & .404 & .051 & .569 & .285 \\
\hline$\%$ African American & .071 & 3.309 & $.000 * * *$ & .072 & 3.370 & $.000 * * *$ \\
\hline$\%$ Latino & .035 & 1.120 & .132 & .039 & 1.272 & .102 \\
\hline$\%$ Native American & .000 & -.035 & .972 & -.001 & -.208 & .836 \\
\hline Principal gender & .252 & .880 & .190 & .205 & .730 & .233 \\
\hline SRO presence & -.068 & -.236 & .814 & -.042 & -.147 & .883 \\
\hline Constant & -1.362 & -1.190 & .236 & -1.371 & -1.198 & .233 \\
\hline Number of schools & & 154 & & & 154 & \\
\hline $\mathrm{R}^{2}$ & & .119 & & & .115 & \\
\hline
\end{tabular}

Note: The dependent variable is the number of the schools special needs students referred to the OJA divided by the by the number of special needs students enrolled in the school. $* \mathrm{p}<.10 ; * * \mathrm{p}<.05 ; * * * \mathrm{p}<.01$. 
Public schools with greater percentages of African American students are more likely to refer greater percentages of special needs students to the OJA (Sig. $=.000)$. The unstandardized estimate indicates that for every one percentage point increase in the enrollment of African American students, referrals of the school's special needs students to the OJA will increase by .071 percentage points. In Model 1, the percentage of African American students enrolled in the school has the greatest effect on the dependent variable (standardized Beta $=.287$ ). The model indicates that no relationship exists between the percentages of the schools special needs students referred to the OJA and the following independent variables: (1) the percentage of the schools special needs population; (2) the percentage of students receiving a free or subsidized lunch; (3) the percentage of out-of-school suspensions by the school; (4) the percentage of Latino students enrolled in the school; (5) The percentage of Native American students enrolled in the school; (6) the presence of a male principal in the school; and (7) the presence of a school resource officer at the school.

The second regression model (Model 2) in Table 4.5 omits the percentage of special needs students enrolled in the school as a variable. In Model 2, the parameter estimates indicate that public schools with greater percentages of male students are more likely to refer greater percentages of special needs students to the OJA (Sig. $=.043$ ). The unstandardized estimate indicates that for every one percentage point increase in the enrollment of male students, referrals of special needs students to the OJA will increase by .034 percentage points. In Model 2, the percentage of male students enrolled in the school has the second greatest effect on the dependent variable ( standardized Beta $=.143$ ).

Model 2 indicates that public schools with greater percentages of African American students are more likely to refer greater percentages of special needs students to the OJA ( $\mathrm{Sig}$. = 
.000). For every one percentage point increase in the enrollment of African American students, referrals of special needs students to the OJA will increase by .072 percentage points. The percentage of African American students enrolled in the school has the greatest effect on the dependent variable $($ standardized Beta $=.291)$.

The parameter estimate indicates that public schools with greater percentages of Latino students is almost significant at $\mathrm{p} \leq .10(\mathrm{Sig} .=.102)$. The regression model indicates that no relationship exists between the percentage of special needs students referred to the OJA and the other independent variables.

\section{Individual School Rankings}

Dependent variable 1: the percentage of students referred to the OJA divided by the total enrollment in the school. In Table 4.6, public schools are ranked based on the percentage of students referred to the OJA divided by the total enrollment in the public school. Only the schools referring in the top five percent of the sample are listed. Hanna Elementary School had the highest percentage of students referred to the OJA with 5.88 percent. ${ }^{23}$ Greasy Public Schools had the second highest percentage of students referred to the OJA with 5.26 percent. ${ }^{24}$ Liberty Public Schools had the third highest percentage of students referred to the OJA with 5.10 percent. For additional rankings for the first dependent variable see Table 4.6 below.

\footnotetext{
${ }^{23}$ Enrollment less than 100 with only one referral.

${ }^{24}$ Enrollment less than 100 with only one referral.
} 
Table 4.6

School Rankings by Referrals of Students to the OJA - Top 5 Percent of the Sample

Dependent Variable 1: the percentage of students referred to the OJA

divided by total enrollment in the public school

\begin{tabular}{llll} 
County & School & Grades & \% Students \\
McIntosh & Hanna Elementary* & PK-8 & 5.88 \\
Adair & Greasy Public School* & PK-8 & 5.26 \\
Sequoyah & Liberty Public Schools & PK-8 & 5.10 \\
McIntosh & Midway High School** & $9-12$ & 3.51 \\
McIntosh & Checotah High School & $9-12$ & 3.43 \\
Haskell & McCurtain High School** & $9-12$ & 3.28 \\
Muskogee & $7^{\text {th }}$ and $8^{\text {th }}$ Grade Center & $7-8$ & 2.92 \\
Muskogee & Muskogee High School $^{*}$ & $9-12$ & 2.70 \\
\hline
\end{tabular}

Note: *schools with enrollment less than 100 students and only one referral; **schools with enrollment less than one hundred students with two referrals. $\mathrm{Pk}-8$ public schools enrollment has been adjusted to reflect $6^{\text {th }}$ through $8^{\text {th }}$ grade only.

\section{Dependent variable 2: the percentage of special needs students referred to the OJA}

divided by the total enrollment in the school. In Table 4.7, public schools are ranked based on the percentage of special needs students referred to the OJA divided by the total enrollment in the public school. Hanna Elementary School had the highest percentage of special needs students referred to the OJA with 5.88 percent. ${ }^{25}$ Greasy Public Schools had the second highest percentage of special needs students referred to the OJA with 5.26 percent. ${ }^{26}$ Midway High

${ }^{25}$ Enrollment less than 100 with only one referral.

${ }^{26}$ Enrollment less than 100 with only one referral. 
School ${ }^{27}$ had the third highest percentage of special needs students referred to the OJA with 1.75 percent. For additional rankings for the second dependent variable see Table 4.7 below.

Table 4.7

School Rankings by Referrals of Special Needs Students to the OJA - Top 5 Percent of the Sample

Dependent Variable 2: the percentage of special needs students referred to the OJA divided by total enrollment of special needs students in the public school

\begin{tabular}{llll} 
County & \multicolumn{1}{c}{ School } & Grades & \% students \\
McIntosh & Hanna Elementary* & PK-8 & 5.88 \\
Adair & Greasy Public School* & PK-8 & 5.26 \\
McIntosh & Midway High School* & $9-12$ & 1.75 \\
Muskogee & $7^{\text {th }}$ and 8 $^{\text {th }}$ Grade Center & $7-8$ & 1.75 \\
Haskell & McCurtain High School* & $9-12$ & 1.64 \\
Muskogee & Muskogee High School & $9-12$ & 1.51 \\
McIntosh & Checotah High School & $9-12$ & 1.29 \\
Muskogee & Webbers Falls High School* & PK-8 & 1.15 \\
\hline
\end{tabular}

Note: *schools with enrollment less than 100 students and only one referral; **schools with enrollment less than one hundred students with two referrals. Pk-8 public schools enrollment has been adjusted to reflect $6^{\text {th }}$ through $8^{\text {th }}$ grade only.

\section{Dependent Variable 3: the percentage of special needs students referred to the OJA} divided by the total enrollment of special needs students in the school. In Table 4.8, public schools are ranked based on the percentage of special needs students referred to the OJA divided by the total enrollment of special needs students in the public school. Muskogee High School

${ }^{27}$ Enrollment less than 100 with only one referral. 
referred the highest percentage of the schools special needs student population to the OJA with 8.19 percent. Muskogee $7^{\text {th }}$ and $8^{\text {th }}$ Grade Center referred the second highest percentage of the schools special needs students to the OJA with 8.11 percent. Checotah High School referred the third highest percentage of the schools special needs students to the OJA with 7.69 percent. For additional rankings for the third dependent variable see Table 4.8 below.

Table 4.8

School Rankings by the Percentage of the Schools Special Needs Student Enrollment Referred to the OJA - Top 5 Percent of the Sample

Dependent Variable 3: the percentage of special needs students referred to the OJA divided by total enrollment of special needs students in the public school

\begin{tabular}{llll} 
County & \multicolumn{1}{c}{ School } & Grades & \% Students \\
Muskogee & Muskogee High School & $9-12$ & 8.19 \\
Muskogee & $7^{\text {th }}$ and $8^{\text {th }}$ Grade Center & $7-8$ & 8.11 \\
McIntosh & Checotah High School & $9-12$ & 7.69 \\
Haskell & McCurtain High School* & $9-12$ & 7.14 \\
Le Flore & Panama Middle School & $7-8$ & 5.88 \\
McIntosh & Hanna Elementary* & PK-8 & 4.76 \\
Le Flore & Cameron High School & $9-12$ & 4.35 \\
Le Flore & Spiro High School & $9-12$ & 4.08 \\
\hline
\end{tabular}

Note: *schools with enrollment less than 100 students and only one referral; **schools with enrollment less than one hundred students with two referrals. Pk-8 public schools enrollment has been adjusted to reflect $6^{\text {th }}$ through $8^{\text {th }}$ grade only.

\section{Summary of Findings}


The descriptive statistics for the dependent variables indicate that $32 \%$ of all referrals to the District 5 of the OJA between August 15, 2011 and June 15, 2012 came from public schools within the district. The percentage of public school populations referred ranged from zero to 5.88 percent. Two public schools in the district referred over eight percent of their special needs population to the OJA. The multiple regression results indicate that at conventional significance levels, the percentage of special needs students enrolled in the school, the percentage of male students enrolled in the school, and the percentage of African American students enrolled in the school are associated in the positive direction with the percentage of students referred to the OJA by public schools in eastern Oklahoma. Furthermore, after removal of the first independent variable (the percentage of special needs students enrolled in the schools), the percentage of students receiving a free/subsidized lunch became significant in the positive direction.

The results indicate that at conventional significance levels, the percentage of special needs students enrolled in the public school, the percentage of male students enrolled in the school, and the percentage of African American students enrolled in the school are associated in the positive direction with the percentage of special needs students referred to the OJA in eastern Oklahoma. After removal of the first independent variable (the percentage of special needs students enrolled in the schools), the percentage of Native American students enrolled in the school became significant in the positive direction.

The percentage of male students enrolled in the school and the percentage of African American students enrolled in the school are related in the positive direction with the percentage of the public school special needs population referred to the OJA in eastern Oklahoma. After removal of the first dependent variable (the percentage of special needs students enrolled in the schools), no additional variables reached significance. 
The following independent variables were not significant in any of the models: (1) the percentage of out-of school suspensions by the school; (2) the percentage of Latino students enrolled in the school; (3) the presence of a male principal in the school; and (4) the presence of a school resource officer in the school.

Several of the less populated rural schools (less than 100 students) reached the top five percent of referrals to the OJA in each model but only because of small enrollment numbers in the school. For public schools with more than 100 students, Checotah High School, Muskogee $7^{\text {th }}$ and $8^{\text {th }}$ Grade Center, and Muskogee High School ranked in the top five percent for referral on each of the three dependent variables. Muskogee $7^{\text {th }}$ and $8^{\text {th }}$ Grade Center and Muskogee High School referred over eight percent of the special needs population enrolled in the school to the OJA within the 2011 and 2012 school year.

In Chapter 5, I discuss of the findings as they relate to the research questions and to previous research, policy implications of the findings, recommendations for future research, and conclusions that can be drawn from the research. Also included in the chapter is a discussion of the limitations of the research. 


\section{Chapter 5}

\section{Summary and Discussion}

\section{Introduction}

This chapter will present a summary of the findings for each research question along with discussion of how the findings fit with existing research. A discussion of the policy implications and recommendations for future research are also included in the chapter.

The school-to-prison pipeline metaphor suggests that public schools are responsible in some systematic fashion for much of the youth population in the juvenile justice system and for supporting the prison-industrial complex. This research, through use of a regional sample, answers three basic questions: (1) do some public schools in eastern Oklahoma refer students to the OJA at greater rates than other public schools in eastern Oklahoma, if so, why, (2) do some schools in eastern Oklahoma refer special needs students to the OJA at greater rates than other public schools in eastern Oklahoma, if so, why, and (3) do some schools in eastern Oklahoma refer a greater percentage of their population of special needs students to the OJA than other schools in eastern Oklahoma, if so, why?

\section{Summary and Discussion of Findings (and relationship to existing research)}

\section{Research Question 1: Do some schools in eastern Oklahoma refer students to the} OJA at greater rates than other schools in eastern Oklahoma? If so, why? Certain public schools in the study had atypically high referral percentages. Liberty Public Schools (5.10), Checotah High School (3.43), Muskogee $7^{\text {th }}$ and $8^{\text {th }}$ Grade Center (2.92), and Muskogee High School (2.70) referred the greatest percentages of their student populations among schools with an enrollment of greater than 100 students. Table 4.6 shows the top five percent of schools with the greatest percentage of referrals. 
The multiple regression results for Model 1 for the first dependent variable, the percentage of students referred to the OJA, indicates that three of the nine hypotheses are supported. These are, (1) the higher the percentage of special needs students enrolled in the public school, the greater the percentage of students referred to the OJA, (2) the higher the percentage of male students enrolled in the public school, the greater the percentage of students referred to the OJA, and (3) the higher the percentage of African American students enrolled in the public school, the greater the percentage of students referred by the school to the OJA. The percentage of African American students enrolled in the school has the strongest effect on the referral of students to the OJA by the public school. The percentage of male students enrolled in the school has the second strongest effect on the dependent variable.

The multiple regression results for Model 2 on the percentage of students referred by the public school supported one additional hypothesis; the higher the percentage of students receiving free or subsidized lunches in the public school, the greater the percentage of students referred to OJA.

These findings contribute to the extant literature on the school-to-prison pipeline metaphor. The school-to-prison metaphor relies on research that suggests public schools are responsible for the overrepresentation of special needs, African American, male, and poor students being suspended, expelled, and referred to juvenile justice agencies (Hatt, 2011; Skiba et al., 2002; Teske and Huff, 2010; Tulman, 2008; Wald and Losen, 2003; Welch and Payne, 2013). The school-to-prison pipeline metaphor also relies on research that exposes the vulnerabilities of these groups for juvenile adjudications leading to school failure and adult incarceration. This study exposes the vulnerability of these groups for referral to juvenile justice agencies and may expose their vulnerability for school failure and adult incarceration (Hatt, 
2011; Houchins et al., 2010; Leone et al., 2002; Wald and Losen, 2003). Certain schools in eastern Oklahoma are referring students to the OJA at greater rates than other schools in eastern Oklahoma and the correlates of these referrals are greater populations of special needs, African American, male, and poor students. A school-to-prison pipeline may exist in eastern Oklahoma.

\section{Research Question 2: Do some schools in eastern Oklahoma refer special needs} students to the OJA at greater rates than other schools in eastern Oklahoma? If so, why?

Certain public schools in the study had atypically high referral percentages of special needs students. Muskogee $7^{\text {th }}$ and $8^{\text {th }}$ Grade Center (1.75), Muskogee High School (1.51), and Checotah High School (1.29) had the greatest percentage of special needs student referrals among schools with enrollments of greater than 100 students. Table 4.7 shows the top five percent of schools with the greatest percentages of special needs student referrals.

The findings for Model 1 for the second dependent variable, the percentage of special needs students referred to the OJA by the public school, show support for three hypotheses. These hypotheses are: (1) the higher the percentage of special needs students enrolled in the public school, the greater the percentage of special needs students referred to the OJA, (2) the higher the percentage of male students enrolled in the public school, the greater the percentage of special needs students referred to the OJA, and (3) the higher the percentage of African American students enrolled in the public school, the greater the percentage of special needs students referred by the school to the OJA. The percentage of African American students enrolled in the school has the strongest effect on the referral of special needs students to the OJA by the public school. The percentage of male students enrolled in the public school, has the second strongest effect on the dependent variable. 
The multiple regression results for Model 2 on the percentage of special needs students referred by the public school supported one additional hypothesis. The higher the percentage of Native American students enrolled in the school, the greater the percentage of special needs students referred to OJA.

Public schools with higher percentages of special needs, male, African American, and Native American students will have a greater rate of referral of special needs students to the OJA in eastern Oklahoma. These findings concur with the extant literature that at-risk students, specifically special needs students, are overrepresented in referrals to juvenile justice agencies. Special needs, male, and African American enrollment are related to the percentage of both referrals to the OJA and referrals of special needs students to the OJA at conventional levels of significance. Native American enrollment is only related to the percentage of special needs student referrals to the OJA at conventional levels of significance. This finding is unique and may support a relationship with Lynn's (2010) research indicating "Native Americans were 1.52 times more suspended that whites" (p. 96). The findings suggest that a school-to-prison pipeline may exist in eastern Oklahoma because some schools refer greater percentages of their special needs students including Native American students to the OJA.

\section{Research Question 3: Do some schools in eastern Oklahoma refer a greater} percentage of their population of special needs students to the OJA than other schools? If so, why? Some public schools in the study had atypically high referral percentages of their special needs population. Checotah High School (7.69), Muskogee $7^{\text {th }}$ and $8^{\text {th }}$ Grade Center (8.11), and Muskogee High School (8.19) referred the greatest percentages of their special needs student population among schools with enrollments of greater than 100 students. Table 4.8 shows the top five percent of schools with the greatest percentage of referrals. 
The findings for Model 1 for the third dependent variable, the percentage of a school's special needs population referred to the OJA by the public school, indicates support for two hypotheses. These are (1) the higher the percentage of male students enrolled in the public school, the greater the percentage of the schools special needs students referred to the OJA, and (2) the higher the percentage of African American students enrolled in the public school, the greater the percentage of the school's special needs students are referred by the school to the OJA. The percentage of African American students enrolled in the school has the strongest effect on the dependent variable. The results for Model 2 on the percentage of the school's special needs students referred by the public school are similar to those for Model 1. This provides additional evidence that is consistent with studies on the vulnerability of special needs students to harsh disciplinary actions by public schools (Hatt, 2011; Teske and Huff, 2010; Tulman, 2008; Wald and Losen, 2003).

These findings establish that higher percentages of certain populations (African American, male, special needs) within the public school are related to higher percentages of referrals to the OJA. This study does not identify the race or gender of the students that were actually referred by the school to the OJA. However, it does identify whether the students referred to the OJA by the school were designated as special needs students. This research indicates that Muskogee High School and the Muskogee $7^{\text {th }}$ and $8^{\text {th }}$ Grade Center referred over eight percent of their special needs populations to the OJA during the 2011-2012 school year. As indicated in the literature, special needs students are overrepresented in the juvenile justice system and this overrepresentation is evidence of a school-to-prison pipeline (Leone et al., 2002; Teske and Huff, 2010; Tulman, 2008; Wald and Losen, 2003). Having two public schools in the same district refer nearly one out of every ten of its special needs students to the juvenile justice 
system clearly supports the school-to-prison pipeline metaphor. Furthermore, the patterns in the data suggest that these schools may be implementing federal special education protocols in a manner that negatively affects the population. More research needs to be conducted that focuses on the schools identified with high rates of special needs referrals to the OJA.

\section{Policy Implications}

Two significant policy implications must be discussed: (1) public school disciplinary policies and (2) improving intervention strategies including culturally sensitive strategies that should be adopted by public schools.

Disciplinary policies. Public policies designed for the prevention of juvenile delinquency carry little political weight because the perceived benefactors are constructed as juvenile delinquents. This is consistent with Rochefort and Cobb's (1994) observations about problem definition. Rochefort and Cobb (1994) state that "social deviants and other out-group members do not receive equivalent consideration to persons with whom the public readily identifies" and "...deviants, such as criminals, are in the worst situation, since they are both weak and negatively constructed" (Rochefort and Cobb, 1994, p. 23).

How social problems are defined not only affects the solutions we offer, these definitions also affect the social construction of target populations (Schneider and Ingram, 1993; Rochefort and Cobb, 1994). "The social construction of target populations refers to the cultural characterizations or popular images of the persons or groups whose behavior and well-being are affected by public policy” (Schneider, and Ingram, 1993, p. 334). Current education policy focuses on disciplinary solutions for problem behavior (Aron and Mears, 2003; Hatt, 2011; Meiners, 2011; Tuzzolo and Hewitt, 2006) and may be socially constructing at-risk populations negatively as deviants that need to be removed from the school. 
Public officials commonly inflict punishment on negatively constructed groups who have little or no power, because they need fear no electoral retaliation from the group itself and the general public approves of punishment for groups that it has constructed negatively. (Schneider, and Ingram, 1993, p. 336)

Since deviants are negatively constructed it is easy for public officials to ignore their needs by creating public policy that may harm them (Schneider, and Ingram, 1993) and in many cases such policy is politically advantages (Arnold, 1990). Rochefort and Cobb (1994) discuss how the definition of a social problem also creates a negative image of certain populations. "Related to these issues is the distinction between sympathetic and threatening populations. Understanding of the nature of the difficulties presented by members of a problem population are [sic] also formative in policy-making" (Rochefort and Cobb, 1994, pp. 22-23). This is particularly problematic for at-risk students including special needs students. The image of special needs children has been manipulated from the sympathetic (disabled child) to the threatening (juvenile delinquent) student that is disruptive in the classroom. Elaine Sharp (1994) provides a good example of this dilemma in her paper on antidrug policy, "on the one hand, the drug users are strange, threatening, and undeserving of sympathy; on the other hand, drug users are the most familiar, sympathetic, and deserving characters of all - our children" (Rochefort and Cobb, 1994, p. 105). The idea that so many of the drug abusers where in fact our children and young adults, has shifted political thought from getting tough on drug use to the legalization of marijuana (Rochefort and Cobb, 1994, p.105). This may provide some insight into how a redefinition of the problem can lead to better policy, especially policy that can reduce the number of special needs students (a sympathetic population) that end up in the juvenile justice system.

Public policy makers are influenced by teachers, parents, and school administrators who may view at-risk students as trouble makers who are too destructive to remain in the community much less the school environment (Ingersoll and LeBoeuf, 1997). Education policy makers such 
as teachers, administrators, and legislators, may be indifferent to at-risk students because they have been negatively constructed. Baumgartner and Jones (1993) state that by "mobilizing the previously indifferent through redefinition of issues, no system based on the shared preferences of the interested is safe" (p. 19). Redefining these youth as troubled kids who have been denied a free and appropriate public education is what may be necessary to reduce their involvement in the juvenile justice and criminal justice systems while allowing public schools to avoid litigation similar to that in Meridian, Mississippi.

Improving intervention strategies to protect at-risk students. Getting the school-toprison pipeline metaphor on a legislative agenda may require an expansion of the scope of conflict (Schattschneider, 1960). This is suggested by Baumgartner and Jones' (1993) description of the Schattschneider mobilization. The Schattschneider mobilization "often stems from the efforts of opponents of the status quo to expand the scope of conflict. Here the government is already involved in the solution, and some have begun to see the solution as the problem" (Baumgartner and Jones, 1993, p. 89). According to the Congressional Record (1996), the debate on current special education policy included a discussion to mandate the use of intervention strategies. The legislative committee debating the reauthorization of the IDEA rejected the idea that they should mandate intervention strategies for special needs children. The committee believed that provisions had been provided in the act to address behavioral issues. According to the committee,

The Act emphasizes a proactive approach to behaviors that interfere with learning by requiring that, for children with disabilities whose behavior impedes their learning or that of others, the IEP Team consider, as appropriate, and address in the child's IEP, the use of positive behavioral interventions, and other strategies to address the behavior (U.S. Department of Education, 2004, p. 2). 
The act only recommends the IEP team "consider" the use of intervention strategies. The strategies should have been mandated by the IDEA reauthorization committee. Legislators may have expected intervention strategies to be used by public schools, but by failing to act on the proposed changes that would mandate intervention they may have left the school-to-prison pipeline open. The intervention strategies suggested by the IDEA should be made mandatory policy not only for special needs students, but all at-risk students in public schools in eastern Oklahoma because it is consistent with policy goals of special education and the public school system.

Policy recommendations. As indicated in the literature review in chapter 2, poverty, race, and special needs may be the biggest predictors of a student becoming involved in the juvenile justice and criminal justice systems (Aron and Mears, 2003; Capella et al, 2008; Laura, 2011; Lynn, 2009; Tullman and Weck, 2009). This study demonstrates that African American, Native American, male, special needs, and poverty have a positive effect on the percentage of students (special needs or otherwise) that a school refers to the OJA. The question then becomes, what can public schools do to reduce the number of at-risk youth being pushed out of school? One answer has already been proposed. According to Llorente (2014), the U. S. Department of Education and the Department of Justice have "issued federal guidelines to advise schools on how to improve the school climate and discipline" (p. 19) by reducing reliance on suspensions and expulsions for minor infractions, and ensuring "fairness and equity for all students" (Llorente, 2014, p. 19). Adoption of these guidelines would be a good first step in reducing the public school footprint on juvenile justice populations.

In March, 2013, the Department of Justice accepted a consent decree with the Meridian Mississippi Public School District. Part of the decree requires the school district to reduce 
suspensions and expulsions of African American students for minor infractions. The decree also requires the school district to eliminate all police intervention involving negative behavior that can be "safely and appropriately handled under school disciplinary procedures" (Mock, 2013, p. 2).

The social impact of harsh disciplinary practices by public schools, while alarming, has failed to garner sufficient attention to initiate changes in zero-tolerance, the use of police to discipline students, and special education policy. Adoption of intervention strategies that reduce the suspensions and expulsions of at-risk students and reduces police involvement for minor infractions that criminalizes at-risk students may reduce the number of students referred to juvenile justice agencies, as well as reduce the need for further litigation like that in Meridian, Mississippi.

\section{Recommendations for Future Research}

Discretionary discipline. First, it is my recommendation that future research be conducted to measure the use of disciplinary discretion in public schools. This study identifies whether the public school is the referral source and whether the school administrators used their discretion to criminalize student behavior by involving law enforcement and the OJA as a disciplinary option. According to this study, 32 percent (see page 57) of the children referred to the OJA were referred by a public school and nearly half of them were special needs students. More data is needed to determine if these referral rates are typical for public schools that may or may not be demographically similar. This research design identifies the variables positively associated with the referral of students by public schools to the OJA. This research method can be duplicated to include each of the OJA districts within the State of Oklahoma, including the metropolitan counties of Oklahoma and Tulsa. Additional analyses will be helpful in 
determining which of the independent variables has the highest positive influence on referrals to the OJA especially if the research included race and gender specific data for each of the referrals to the OJA by the public school.

Another recommendation for future research would include adding an additional dependent variable to the methodology. It the course of this study we discovered the percentage of the public schools special needs population that had been referred to the OJA. It would be beneficial to compare this with the percentage of the schools non-special needs students referred by the public school to the OJA to determine if the schools were equally punitive to both populations.

Native American students. Second, eastern Oklahoma has a large population of Native American students. Lynn (2010) suggests that Native American students are 1.52 times more likely to be arrested than white students. I suggest that additional research be conducted that focuses on the relationship between Native American and special needs students and referrals to the OJA. The percentage of Native American students enrolled in the public school is positively related to the percentage of special needs students referred to the OJA (see Table 4.4, p. 66). I believe more study is needed that examines the relationship between these two correlates. I also recommend further study to identify the percentage of Native Americans being referred by public schools to the OJA and the percentage of that population that has an IEP. This would be helpful in determining whether a positive relationship exists between greater referrals of special needs students to the OJA and greater rates of Native American students with disabilities enrolled in the school.

African American students. Third, I recommend further study that identifies the percentage of African American students referred by the public schools in eastern Oklahoma. 
Part of the consent decree between the U.S. Justice Department and Meridian, Mississippi requires the school districts to track discipline data that includes race. If the data reflects racial disparities the district is to take corrective action. According to the U.S. Justice Department, the consent decree should serve as a "blueprint for school districts across the country" (Mock, 2013, p. 2). This study did not measure how many of the referrals were African American. It only examined whether the percentage of African Americans enrolled in the school is related to greater referral percentages to the OJA. It would be beneficial to see how many of the referrals were of African American students. Moreover, using data at the individual level, it would be useful to compare public school referrals to OJA to other referrals to the OJA to see if youth are being referred for the same kind of alleged offenses.

School resource officers. Finally, this research evaluates the effect the presence of an SRO in the public school has on referrals to the OJA. The extant literature suggests, at least in urban public schools, that the presence of an SRO on the campus of a public school increases referrals to the juvenile justice system (Beger, 2002; Teske \& Huff, 2010; Theriot, 2011). My research does not support a positive relationship between the presence of an SRO on campus and higher percentages of student referrals to the OJA. This is inconsistent with the extant literature (Beger, 2002; Teske \& Huff, 2010; Theriot, 2011). While no positive relationship is indicated in this research, additional models would have to be run to show firmer conclusions regarding the negative relationships indicated in the models (see Tables 4.3, 4.4, and 4.5). My recommendation would be to use this research model to further examine schools with an SRO on campus.

\section{Conclusion}

The literature provides many examples indicating that a school-to-prison pipeline may exist including zero-tolerance and safety-first policies, the presence of police officers (SRO's) in 
our public schools, and changes in special education policy that dilute protections for special needs students against suspensions and expulsions. The research on the school-to-prison pipeline indicts the use of zero-tolerance, safety first policies, and the implementation of changes to special education policy by public schools (Johnson \& Womack, 2013; Tuzzolo \& Hewitt, 2006; Wald \& Losen, 2003). My research does not intend to support or dispel the use of these policies as a predictor of a school-to-prison pipeline in eastern Oklahoma, nor does my research suggest that these policies are fully practiced by public schools in the sample. However, the results of this study are consistent with the existence of a school-to-prison pipeline in eastern Oklahoma. This research indicates that higher percentages of special needs students enrolled in the public school is related to higher percentages of referrals to the OJA. This may be evidence of a negative outcome from changes in special education protocols which, according to much of the literature, has diluted many of the previous protections deemed necessary in the public school setting to prevent unnecessary expulsions and suspensions (Leone et al, 2002; National Council on Disability, 2002; Raskin, 2004; U.S. Dept. of Ed., 2007). This also may be evidence of zerotolerance and safety first policies negatively impacting special needs populations (Aron \& Mears, 2003; Leone et al, 2002; Raskin, 2004). Taken together these changes in policy could support and help create a school culture in which a school-to-prison pipeline is rarely questioned.

This research combined with the extant literature exposes gender, poverty, race, and special needs as demographic predictors that contribute to the school-to-prison pipeline. When examining the percentage of students referred to the OJA, poverty was a significant contributor to referrals to the OJA, specifically, the greater the percentage of students receiving a free or subsidized lunch, the greater the percentage of referrals to the OJA. Thus, this research supports the literature that identifies poverty as a factor associated with the school-to-prison pipeline. 
This research is also consistent with the extant literature that identifies race as a factor associated with the school-to-prison pipeline metaphor. In one model, the greater the percentage of Native American students enrolled in the public school, the greater the percentage of special needs students referred to the OJA. In each of the models, the percentage of African American students showed a statistically significant association with referrals to the OJA. In fact, the percentage of African American students is usually the most important variable in each model. The findings support the literature that suggests that race and poverty put students at risk for harsh disciplinary actions by public school (Lamarche, 2011). According to Lamarche (2011), 45 percent of all school arrests were of African American students.

According to the literature and this research, male students are particularly vulnerable for disciplinary actions in our public schools (Skiba et al., 2002; Welch and Payne, 2013). In each of the models male enrollment in the public school is related to higher percentages of referrals to the OJA by the public school.

Finally, this research supports previous research that suggests students with special needs are particularly vulnerable for referral to the juvenile justice system. 32 percent of all referrals to the OJA during this study came from public schools and nearly half of the students referred had at least one special need. Muskogee $7^{\text {th }}$ and $8^{\text {th }}$ Grade Center and Muskogee High School referred over eight percent of their special needs population to the OJA during the 2011-2012 school year. The multivariate analysis supports the hypothesis that the higher the percentage of special needs students enrolled in the public school, the higher the percentage of students referred to the OJA.

The data analysis supports an affirmative response to each of the three primary research questions. Future research on the school-to-prison pipeline should examine data at the individual 
level comparing public school referrals of African American, Native American, male, special needs, and poor students to the OJA with other populations. Data at the individual level will also be useful to determine if students are being referred by public schools to juvenile justice agencies for similar offenses as students being referred by other sources outside of the school.

The results of this study show a relationship between the percentage of African American, percentage of Native American students, percentage of male students, percentage of special needs students, percentage of students receiving a free and/or subsidized lunch enrolled in the school and increases in the percentage of students referred by the public school to the OJA intake offices in eastern Oklahoma. 


\section{References}

Adams, B., \& Addie, S. (2010). Delinquency cases waived to criminal court, 2007 (Report No. NCJ 230167). Office of Juvenile Justice and Delinquency Prevention. Retrieved from https://www.ncjrs.gov/pdffiles 1/ojjdp/230167.pdf

Anderson, James E. (2011). Public Policymaking ( $7^{\text {th }}$ Ed.). Boston, MA: Wadsworth Cengage Learning

Anderson, R. W. (2012, July 30). Reports: County poverty numbers increasing. Tahlequah Daily Press. Retrieved from http://www.tahlequahdailypress.com

Attorney General and Education Secretary announce joint project to address school disciplinary practices. (2011, July 21). Office of Juvenile Justice and Delinquency Prevention. Retrieved from https://www.ncjrs.gov/html/ojjdp/news_at_glance/235188/sf_1.html

Aull, I. H. (2012). Zero tolerance, frivolous juvenile court referrals, and the school-to-prison pipeline: Using arbitration as a screening-out method to help plug the pipeline. Ohio State Journal on Dispute Resolution, 27(1), 179-206.

Averill, M. (2012, February 9). In Oklahoma, support for children lacking; study says state ranks $49^{\text {th }}$. Tulsa World. Retrieved from http://www.tulsaworld.com

Beccaria, C. (1764). Of Crimes and Punishment. New York: Marsilio.

Beck, A. N., \& Muschkin, C.G. (2012). The enduring impact of race: Understanding disparities in student disciplinary infractions and achievement. Sociological Perspectives, 55(4), 637-662. doi: http://dx.doi.org/10.1525/sop.2012.55.4.637

Baumgartner, F. R., \& Jones, B. D. (1993). Agendas and Instability in American Politics. Chicago: University of Chicago Press.

Beger, R. R. (2002). Expansion of police power in public schools and the vanishing rights of students. Social Justice, 29, 1-2.

Bon, S. C., Fairchild, S., \& LeTendre, G. K. (2006). The school violence dilemma: Protecting the rights of students with disabilities while maintaining teachers' sense of safety in schools. Journal of Disability Policy Studies, 17(3), 148-157.

Boothby, R. S. (2002). Safety first: Student discipline under the 1997 amendments to the IDEA and the need for further reform. Ohio State Law Journal, 63, 1683.

Brown, J. D., Riley, A. W., Walrath, C. M., Leaf, P. J., \& Valdez, C. (2008). Academic achievement and school functioning among nonincarcerated youth involved with the juvenile justice system. Journal of Education for Students Placed at Risk, 13(1), 59-75.

Cappella, E., Frazier, S. L., Atkins, M. S., Schoenwald, S. K., \& Glisson, C. (2008). Enhancing schools' capacity to support children in poverty: An ecological model of school-based 
mental health services. Administration and Policy in Mental Health and Mental Health Services Research, 35(5), 395-409. doi: http://dx.doi.org/10.1007/s10488-008-0182-y

Chira, S. (1993, May 19). When disabled students enter regular classrooms. New York Times. Retrieved from http://www.nytimes.com

Cole, G. F., \& Smith, C. E. (2010). The American system of criminal justice (12 ${ }^{\text {th }}$ ed.). Belmont, CA: Wadsworth, Cengage Learning.

Comstock-Galagan, J., \& Brownstein, R. (2006). Stopping the schoolhouse to jailhouse pipeline by enforcing special education law. Southern Poverty Law Center. Retrieved from http://www.splcenter.org

Cook, B. G. (2004). Inclusive teachers' attitudes toward their students with disabilities: A replication and extension. The Elementary School Journal, 104(4), 307-320.

Cullen, F. T., \& Agnew, R. (2011). Criminological theory: Past to present ( ${ }^{\text {th }}$ Ed.). New York: Oxford University Press.

Elrod, P., \& Ryder, R. S. (2005). Juvenile justice: A social, historical, and legal perspective (2 ${ }^{\text {nd }}$ Ed.). Burlington, MA: Jones \& Bartlett.

Frieden, T. (2012, October 26). Mississippi town sued over 'school-to-prison pipeline'. Cable News Network. Retrieved from http://www.cnn.com

Hatt, B. (2011). Still I rise: Youth caught between the worlds of schools and prisons. The Urban Review, 43(4), 476-490. doi: http://dx.doi.org/10.1007/s11256-011-0185-y

Healey, Joseph F. (2009). Statistics: A Tool for Social Research ( $8^{\text {th }}$ ed.). Belmont, CA: Wadsworth, Cengage Learning.

Houchins, D. E., Jolivette, K., Shippen, M. E., \& Lambert, R. (2010). Advancing high-quality literacy in juvenile justice: Methodological and practical considerations. Behavioral Disorders, 36(1), 61-69.

Ingersoll, S., \& LeBoeuf, D. (1997, February). Reaching out to youth out of the education mainstream (Bulletin No. NCJ 163920). U.S. Department of Justice, Office of Juvenile Justice and Delinquency Prevention. Retrieved from https://www.ncjrs.gov/pdffiles/163928.pdf

Jackson, A. (2002). Police-school resource officers' and students' perception of the police and offending. Policing, 25(3), 631-650. Retrieved from http://0search.proquest.com.library.uark.edu/docview/211240974?accountid=8361

Johnson, D., \& Womack, G. (2013, Jan 22). Opinion: Why the U.S. must dismantle the schoolto-prison pipeline. National Journal. Retrieved from http://www.nationaljournal.com 
Kresnak, J. (2004, July 7). Lack of mental help keeps kids locked up: Stays in detention cost millions, survey finds. Detroit Free Press. Retrieved from http://www.bridges4kids.org/articles/7-04/FREEP7-7-04.html\#top

Llorente, M. (2014, April 10). Help Us Dismantle the School-to-Prison Pipeline. Children's Rights Litigation, 16(3), 13-21. Retrieved from http://web.a.ebscohost.com.library.uark.edu/ehost/delivery?sid=cfd

Lamarche, G. (2011). The time is right to end 'zero tolerance.' Education Week, 30(19), 5.

Laura, Crystal T. (2011). Reflections on the racial web of discipline. Monthly Review, 63(3), 87.

Leone, P. E., Christle, C. A., Nelson, C. M., Skiba, R., Frey, A., \& Jolivette, K. (2003, October). School failure, race, and disability: Promoting positive outcomes, decreasing vulnerability for involvement with the juvenile delinquency system (EDJJ Report). Retrieved from the National Center on Education, Disability, and Juvenile Justice website: http://www.edjj.org/Publications/list/leone_et_al-2003.pdf

Leone, P. E., \& Meisel, S. M. (1997). Improving education services for students in detention and confinement facilities. Children's Legal Rights Journal, 17(1), 1-12. Retrieved from: www.edjj.org/publications/list/leone_meisel-1997.html

Leone, P. E., Meisel, S. M., \& Drakeford, W. (2002). Special education programs for youth with disabilities in juvenile corrections. Journal of Correctional Education, 53(2), 46-50.

Lynn, R. (2009). Race differences in school exclusions and anti-social behavior. Mankind Quarterly, 50(1), 95-105. Retrieved from http://0search.proquest.com.library.uark.edu/docview/222513226?accountid=8361

May, D. C., Fessel, S. D., \& Means, S. (2004). Predictors of principals' perceptions of school resource officer effectiveness in Kentucky. American Journal of Criminal Justice, 29(1), 75-93. Retrieved from http://0search.proquest.com.library.uark.edu/docview/203518752?accountid=8361

Mears, D., \& Aron, L. (2003). Addressing the needs of youth with disabilities in the juvenile justice system: The current state of knowledge. Washington, DC: National Council on Disability.

Meiners, E. R. (2011). Ending the school-to-prison pipeline/building abolition futures. Urban Revue, 43, 547-565.

Meiners, E. R., \& Winn, M. T. (2010). Resisting the school to prison pipeline: The practice to build abolition democracies. Race, Ethnicity, and Education, 13(3); 271-276.

McIntosh, K., Flannery, K., Sugai, G., Braun, D., \& Cochrane, K. (2008). Relationships between academics and problem behavior in the transition from middle school to high school. Journal of Positive Behavior Interventions, 10(4), 243-255. 
Mock, B. (2013, May 31). Good news in Mississippi: School-to-prison pipeline closes. Color Lines. Retrieved from http://www.colorlines.com

Morris, E. W. (2005). "Tuck in that shirt!" Race, class, gender, and discipline in an urban school. Sociological Perspectives, 48(1), 25-48. Retrieved from http://0search.proquest.com.library.uark.edu/docview/213989096?accountid=8361

National Council on Disability (2002). Addressing the needs of youth with disabilities in the juvenile justice system: The current status of evidenced-based research (NCD Report). Retrieved from http://www.ncd.gov

New department of education report documents huge racial disparities in school discipline. (2012, March 9). Journal of Blacks in Higher Education. Retrieved from http://www.jbhe.com/2012/03/new-department-of-education-report-documents-hugeracial-disparities-in-school-discipline/

Nikulina, V., Widom, C. S., \& Czaja, S. (2011). The role of childhood neglect and childhood poverty in predicting mental health, academic achievement and crime in adulthood. American Journal of Community Psychology, 48(3-4), 309-321. doi: http://dx.doi.org/10.1007/s10464-010-9385-y

Osgood, D., Foster, E., \& Courtney, M. E. (2010). Vulnerable populations and the transition to adulthood. Future of Children, 20(1), 209-229.

Palm Beach County Student Is Criminalized And Placed In Chokehold For A Dress Code Violation. (2007, January). Advancement Project. Retrieved from http://www.advancementproject.org/news-display-aticle.php?content_news_id=40

Price, P. (2009). When is a police officer an officer of the law?: The status of police officers in schools. Journal of Criminal Law \& Criminology, 99(2), 541-570. Retrieved from http://0-search.proquest.com.library.uark.edu/docview/218456816?accountid=8361

Raskin, I. (2004). Manifestation destiny: The school to prison pipeline. Unpublished manuscript, Juvenile Justice Center, Suffolk University Law School, Boston, Massachusetts. Retrieved from https://www.suffolk.edu/documents/Law_jjc_pdfs/ManifestationDestiny.pdf

Reddington, F. P., Bonham, Jr., G. (2012). Flawed criminal justice policies: At the intersection of the media, public fear and legislative response. Durham, NC: Carolina Academic Press.

S. Res.1856. 104 Cong., 142 Cong. Rec. 85 (1996). Retrieved from http://www.gpo.gov/fdsys/pkg/CREC-1996-06-11

Schattschneider, E.E. (1960). The Semi-Sovereign People. New York: Holt, Rinehart and Winston. 
Schneider, A., \& Ingram, H. (1993). Social construction of target populations: Implications for politics and policy. American Political Science Review, 87(2), 334-347.

Skiba, R. J., Michael, R. S., Nardo, A. C., \& Peterson, R. L. (2002). The color of discipline: Sources of racial and gender disproportionality in school punishment. The Urban Review, $34,317-342$.

Slaughter-Defoe, D., \& Carlson, K. G. (1996). Young African American and Latino children in high-poverty urban schools: How they perceive school climate. The Journal of Negro Education, 65(1), 60-70. Retrieved from http://0search.proquest.com.library.uark.edu/docview/222070256?accountid=8361

Taylor, R. W., \& Fritsch, E. J. (2011). Juvenile justice: Policies, programs, and practices $\left(3^{\text {rd }}\right.$ Ed.). New York: McGraw-Hill.

Teske, S.C., \& Huff, B. (2010). The paradox of education in America: Integrating systems for children with disabilities. Children's Litigation, 12(3), 1-15.

Theriot, M. T. (2011). School resource officers in middle grades school communities. Middle School Journal, 42(4), 56-64. Retrieved from http://0search.proquest.com.library.uark.edu/docview/869122093?accountid=8361

Townsend, B. L. (2000). The disproportionate discipline of African American learners: Reducing school suspensions and expulsions. Exceptional Children, 66(3), 381-391. Retrieved from http://0-search.proquest.com.library.uark.edu/docview/201092878?accountid=8361

Tulman, J. B. (2008). Time to reverse the school-to-prison pipeline. Policy \& Practice, 66(1), 22.

Tulman, J. B., \& Weck, D. M. (2009). Shutting off the school-to-prison pipeline for status offenders with education-related disabilities. New York Law School Law Review, 54, 875907.

Tuzzolo, E. T., \& Hewitt, D. T. (2006). Rebuilding inequity: The Re-emergence of the school-toprison pipeline in New Orleans. High School Journal, 90(2), 59-68.

U.S. Bureau of the Census. (2005-2009). American community survey. Washington, DC: Government Printing Office.

U.S. Bureau of the Census. 2010. American community survey. Washington, DC: Government Printing Office.

U.S. Commission on Civil Rights. (2002). Recommendations for the reauthorization of the individuals with disabilities act. Retrieved from http://www.law.umaryland.edu/marshall/usccr/documents/IDEACRbriefing.pdf

U.S. Department of Education. (2007). A 25 year history of the IDEA. Retrieved from http://www2.ed.gov/policy/speced/leg/idea/history.html 
U.S. Department of Education (2004). Building the legacy: IDEA. Retrieved from http://idea.ed.gov/explore/view/p/\%2croot\%2Cregs\%2Cpreamble2\%2Cprepart2\%2CE\% $2 \mathrm{C}$

U.S. Department of Education. (2001). Twenty-third annual report to Congress on the implementation of the Individuals with Disabilities Education Act. Retrieved from https://www2.ed.gov/about/reports/annual/osep/2001/toc-execsum.pdf

U.S. Government Accountability Office. (2003). Special education: Clearer guidance would enhance implementation of federal disciplinary provisions (Report No. GAO-03-550). Retrieved from http://www.gao.gov/products/GAO-03-550

Waintrup, M. G., \& Unruh, D. K. (2008). Career development programming strategies for transitioning incarcerated adolescents to the world of work. The Journal of Correctional Education, 59(2), 127-144.

Wald, J., \& Kurlaender, M. (2003). Connected in Seattle? An exploratory study of student perceptions of discipline and attachments to teachers. New Directions for Youth Development, 99, 35-54.

Wald, J., \& Losen, D. J. (2003). Defining and redirecting a school-to-prison pipeline. New Directions for Youth Development, 2003(99), 9-15.

Welch, K., Payne, A. A. (2010). Racial threat and punitive school discipline. Social Problems, 57(1), 25-48. 


\section{Appendix A}

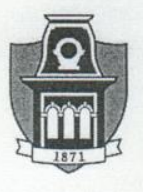

\section{UN I VERS I T Y O F ARKANSAS}

Office of Research Compliance Institutional Review Board

January 18,2013

MEMORANDUM

TO:

FROM:

RE:

IRB Protocol \#:

Protocol Title:

Review Type:

Approved Project Period:
Brett Fitzgerald

Brinck Kerr

Ro Windwalker IRB Coordinator

New Protocol Approval

$13-01-398$

Incarcerating Exceptional Pupils: Is There a School-to-Prison Pipeline in Eastern Oklahoma?

$\triangle$ EXEMPT $\square$ EXPEDITED $\square$ FULL IRB

Start Date:01/18/2013 Expiration Date: 01/17/2014

Your protocol has been approved by the IRB. Protocols are approved for a maximum period of one year. If you wish to continue the project past the approved project period (see above), you must submit a request, using the form Continuing Review for IRB Approved Projects, prior to the expiration date. This form is available from the IRB Coordinator or on the Research Compliance website (http://vpred.uark.edu/210.php). As a courtesy, you will be sent a reminder two months in advance of that date. However, failure to receive a reminder does not negate your obligation to make the request in sufficient time for review and approval. Federal regulations prohibit retroactive approval of continuation. Failure to receive approval to continue the project prior to the expiration date will result in Termination of the protocol approval. The IRB Coordinator can give you guidance on submission times.

This protocol has been approved for $\mathbf{8 0 0}$ participants. If you wish to make any modifications in the approved protocol, including enrolling more than this number, you must seek approval prior to implementing those changes. All modifications should be requested in writing (email is acceptable) and must provide sufficient detail to assess the impact of the change.

If you have questions or need any assistance from the IRB, please contact me at 210 Administration Building, 5-2208, or irb@uark.edu. 


\section{Appendix B}

On Fri, Jan 25, 2013 at 9:51 AM, NSU IRB <irb@nsuok.edu> wrote:

Human Subjects Review

Proposal Title: Incarcerating exceptional pupils: is there a school-to-prison pipeline in Eastern Oklahoma?

IRB \#: 13-088

Dear Mr. Fitzgerald

Your research proposal has been approved by the Institutional Review Board at Northeastern State University in reciprocity with your approval by the University of Arkansas' IRB. It is the IRB's opinion that you have provided adequate safeguards for the welfare of the participants in this study. You are authorized to begin your research and implement this study for the approved duration of the University of Arkansas .If you would like to receive this permission on IRB letterhead, please send a self-addressed stamped envelope or email me where you would like to have an interoffice mail envelope sent.

This approval is granted with the understanding that the research will be conducted within the published guidelines of the NSU Institutional Review Board and as described in your application. Any changes or modifications to the approved protocols should be submitted to the IRB for approval if they could affect the safety, rights, and welfare of the participants in your study. Please use the IRB number in all your communications.

Thank you for sending us your application for research involving human subjects. In doing so, you safeguard the welfare of participants in your study and federal funding of our university.

Signed:__Ernst Bekkering, Ph.D.

Ernst Bekkering

Chair, Institutional Review Board

Ernst Bekkering, Ph.D.

Chair, NSU Institutional Review Board

Email: irb@nsuok.edu

Office: (918) 444-2917

Room 221i

College of Business and Technology

700 N. Grand Avenue

Tahlequah, OK 74464 
Appendix C-Complete School List by County with Findings (dependent variables)

\begin{tabular}{|l|c|c|c|}
\hline Name of Schools by County & $\begin{array}{c}\text { Percentage of } \\
\text { Student Referrals }\end{array}$ & $\begin{array}{c}\text { Percentage of } \\
\text { Special Needs } \\
\text { Students referred }\end{array}$ & $\begin{array}{l}\text { Percentage of } \\
\text { special needs } \\
\text { population referred }\end{array}$ \\
\hline Adair County & 0 & 0 \\
Cave Springs Elementary & 0 & 0 & 0 \\
Cave Springs High School & 0 & 0 & 0 \\
Dahlonegah Public School & 2.56 & 5.26 & 2.33 \\
Greasy Public School & 5.26 & 0 & 0 \\
Maryetta Public School & 0 & 0 & 0 \\
Peavine Public School & 0 & 0 & 0 \\
Rocky Mountain School & 0 & 0 & 0 \\
Skelly Public School & 0 & 0.17 & 0.82 \\
Stilwell High School & 0.17 & 0 & 0 \\
Stilwell Middle School & 0.36 & 0 & 0 \\
Watts High School & 1.63 & 0 & 0 \\
Westville High School & 0 & 0 & 0 \\
Westville Jr. High & 0.65 & 0 & 0 \\
Zion Public School & 0 & 0 & 0 \\
Cherokee County & 0 & 0 & 0 \\
Briggs Public School & 0 & 0 & 0 \\
Grandview Public School & 0 & 0 & 0 \\
Hulbert High School & 0 & 0 & 0 \\
Hulbert Jr. High School & 0 & 0 & 0 \\
Keys High School & 0 & 0 & 0 \\
Lowery Public Schools & 0 & 0 & 0 \\
Norwood Public Schools & 0 & 0 & 0 \\
Peggs Public Schools & 0 & 0 & 0 \\
Shady Grove Schools & 0 & 0.17 & 0 \\
Tahlequah High School & 0.33 & 0.23 & 0 \\
Tahlequah Middle School & 0.81 & 0 & 0 \\
Tenkiller Public School & 0 & 0 & 0 \\
Woodall Public School & 0 & 0 & 0 \\
Haskell County & 0 & 0 & 0 \\
Kinta High School & 0 & 0 & 0 \\
Kinta Elementary School & 0 & 0 & 0 \\
Keota Elementary School & 1.14 & 0 & 0 \\
Keota High School & 0 & 0 & 0 \\
McCurtain Elementary & 0.28 & 0 & 0 \\
McCurtain High School & 0.55 & 0 & 0 \\
Stigler High School & 0 & 0 & 0 \\
Stigler Middle School & 0 & 0 \\
Whitefield Public School & 0 & 0 & 0 \\
& 0 & 0 & 0 \\
\hline
\end{tabular}


Appendix C-Continued

\begin{tabular}{|c|c|c|c|}
\hline Name of Schools by County & $\begin{array}{l}\text { Percentage of } \\
\text { Student Referrals }\end{array}$ & $\begin{array}{l}\text { Percentage of } \\
\text { Special Needs } \\
\text { Students referred }\end{array}$ & $\begin{array}{l}\text { Percentage of } \\
\text { special needs } \\
\text { population referred }\end{array}$ \\
\hline \multicolumn{4}{|l|}{ Le Flore County } \\
\hline Arkoma High School & 0 & 0 & 0 \\
\hline Bokoshe High School & 0 & 0 & 0 \\
\hline Bokoshe Jr. High School & 2.44 & 0 & 0 \\
\hline Cameron Elem. School & 0 & 0 & 0 \\
\hline Cameron High School & 0.91 & 0.91 & 4.35 \\
\hline Fanshawe Public School & 0 & 0 & 0 \\
\hline Heavener Elem. School & 0.47 & 0 & 0 \\
\hline Heavener High School & 0.66 & 0.33 & 1.82 \\
\hline Hodgen Public School & 0 & 0 & 0 \\
\hline Howe Elementary School & 0 & 0 & 0 \\
\hline Howe High School & 0 & 0 & 0 \\
\hline LeFlore Elem. School & 0 & 0 & 0 \\
\hline LeFlore High School & 0 & 0 & 0 \\
\hline Panama High School & 0.51 & 0 & 0 \\
\hline Panama Middle School & 2.44 & 0.81 & 5.88 \\
\hline Panama Upper Elementary & 0 & 0 & 0 \\
\hline Pansy Kidd Public School & 0.38 & 0.38 & 2.13 \\
\hline Pocola High School & 0 & 0 & 0 \\
\hline Pocola Middle School & 0 & 0 & 0 \\
\hline Poteau High School & 0.64 & 0.48 & 2.54 \\
\hline Shady Point Public School & 0 & 0 & 0 \\
\hline Singleton Elem. School & 0 & 0 & 0 \\
\hline Spiro High School & 0.86 & 0.58 & 4.08 \\
\hline Spiro Middle School & 0 & 0 & 0 \\
\hline Talihina High School & 0.65 & 0 & 0 \\
\hline Talihina Jr. High School & 0 & 0 & 0 \\
\hline Whitesboro Elem. School & 0 & 0 & 0 \\
\hline Whitesboro High School & 0 & 0 & 0 \\
\hline Wister Elem. School & 0 & 0 & 0 \\
\hline Wister High School & 0 & 0 & 0 \\
\hline McIntosh County & & & \\
\hline Checotah High School & 3.43 & 1.29 & 7.69 \\
\hline Checotah Middle School & 0.79 & 0.53 & 3.70 \\
\hline Eufaula High School & 2.12 & 0.80 & 3.03 \\
\hline Eufaula Middle School & 0 & 0 & 0 \\
\hline Hanna Elem. School & 5.88 & 5.88 & 4.76 \\
\hline Hanna High School & 0 & 0 & 0 \\
\hline Midway Elem. School & 0 & 0 & 0 \\
\hline Ryal Elem. School & 0 & 0 & 0 \\
\hline
\end{tabular}


Appendix C- Continued

\begin{tabular}{|c|c|c|c|}
\hline Name of Schools by County & $\begin{array}{l}\text { Percentage of } \\
\text { Student Referrals }\end{array}$ & $\begin{array}{l}\text { Percentage of } \\
\text { Special Needs } \\
\text { Students referred }\end{array}$ & $\begin{array}{l}\text { Percentage of } \\
\text { special needs } \\
\text { population referred }\end{array}$ \\
\hline $\begin{array}{l}\text { Stidham Public School } \\
\text { Muskogee County }\end{array}$ & 0 & 0 & 0 \\
\hline Ben Franklin & 0 & 0 & 0 \\
\hline Braggs Elementary & 0 & 0 & 0 \\
\hline Braggs High School & 1.72 & 0 & 0 \\
\hline Ft. Gibson High School & 0.34 & 0.34 & 2.27 \\
\hline Ft. Gibson Middle School & 0.24 & 0.24 & 1.52 \\
\hline Haskell High School & 0 & 0 & 0 \\
\hline Haskell Middle School & 0 & 0 & 0 \\
\hline Hilldale High School & 0.40 & 0.40 & 2.78 \\
\hline Hilldale Middle School & 0 & 0 & 0 \\
\hline Muskogee High School & 2.71 & 1.51 & 8.19 \\
\hline Muskogee $7^{\text {th }}$ and $8^{\text {th }}$ & 2.92 & 1.75 & 8.11 \\
\hline Oktaha Elem. School & 0 & 0 & 0 \\
\hline Oktaha High School & 0.43 & 0 & 0 \\
\hline Porum Elem. School & 0 & 0 & 0 \\
\hline Porum High School & 1.49 & 0 & 0 \\
\hline Sadler Arts Academy & 1.08 & 1.08 & 2.13 \\
\hline Wainwright Public Schools & 0 & 0 & 0 \\
\hline Warner Elem. School & 0.56 & .56 & 0.70 \\
\hline Warner High School & 0 & 0 & 0 \\
\hline Webbers Falls Elementary & 1.85 & 0 & 0 \\
\hline $\begin{array}{l}\text { Webbers Falls High School } \\
\text { Okfuskee County }\end{array}$ & 1.15 & 1.15 & 3.70 \\
\hline Beardon Public School & 0 & 0 & 0 \\
\hline Graham Elem. School & 0 & 0 & 0 \\
\hline Graham High School & 0 & 0 & 0 \\
\hline Mason Elem. School & 0 & 0 & 0 \\
\hline Mason High School & 0 & 0 & 0 \\
\hline Okemah High School & 1.38 & 0.34 & 1.12 \\
\hline Okemah Middle School & 1.98 & 0.50 & 1.49 \\
\hline Paden Elem. School & 0 & 0 & 0 \\
\hline Paden High School & 0 & 0 & 0 \\
\hline Weleetka High School & 0 & 0 & 0 \\
\hline Weleetka Jr. High School & 0 & 0 & 0 \\
\hline Okmulgee County & & & \\
\hline Beggs High School & 0 & 0 & 0 \\
\hline Beggs Middle School & 0 & 0 & 0 \\
\hline
\end{tabular}


Appendix C- Continued

\begin{tabular}{|c|c|c|c|}
\hline Name of Schools by County & $\begin{array}{l}\text { Percentage of } \\
\text { Student Referrals }\end{array}$ & $\begin{array}{l}\text { Percentage of } \\
\text { Special Needs } \\
\text { Students referred }\end{array}$ & $\begin{array}{l}\text { Percentage of } \\
\text { special needs } \\
\text { population referred }\end{array}$ \\
\hline Dewar Elem. School & 0 & 0 & 0 \\
\hline Dewar High School & 0 & 0 & 0 \\
\hline Henryetta High School & 0 & 0 & 0 \\
\hline Henryetta Middle School & 0 & 0 & 0 \\
\hline Morris High School & 0 & 0 & 0 \\
\hline Morris Middle School & 0 & 0 & 0 \\
\hline Okmulgee High School & 0.28 & 0.28 & 1.1 \\
\hline Okmulgee Middle School & 0.59 & 0.3 & 0.96 \\
\hline Preston Elem. School & 0 & 0 & 0 \\
\hline Preston High School & 0 & 0 & 0 \\
\hline Schulter Elem. School & 0 & 0 & 0 \\
\hline Schulter High School & 2.17 & 0 & 0 \\
\hline Twin Hills Public School & 0 & 0 & 0 \\
\hline Wilson Elem. School & 0 & 0 & 0 \\
\hline Wilson High School & 0 & 0 & 0 \\
\hline Sequoyah County & & & \\
\hline Belfonte Bell Elem. School & 0 & 0 & 0 \\
\hline Belfonte Public School & 0 & 0 & 0 \\
\hline Brushy Public School & 0 & 0 & 0 \\
\hline Central Elementary School & 0 & 0 & 0 \\
\hline Central High School & 0 & 0 & 0 \\
\hline Gans Elementary School & 0 & 0 & 0 \\
\hline Gans High School & 0 & 0 & 0 \\
\hline Gore High School & 0 & 0 & 0 \\
\hline Gore Upper Elem. School & 0 & 0 & 0 \\
\hline Liberty Public Schools & 5.1 & 1.02 & 1.18 \\
\hline Marble City Public School & 0 & 0 & 0 \\
\hline Moffett Public School & 0 & 0 & 0 \\
\hline Muldrow High School & 0 & 0 & 0 \\
\hline Muldrow Middle School & 0.43 & 0.22 & 0.93 \\
\hline Roland High School & 0.3 & 0 & 0 \\
\hline Roland Jr. High School & 0 & 0 & 0 \\
\hline Sallisaw High School & 1.84 & 0.77 & 3.73 \\
\hline Tommy Spears Middle & 1.15 & 0.46 & 2.11 \\
\hline Vian High School & 0 & 0 & 0 \\
\hline Vian Middle School & 1.79 & 0.45 & 1.72 \\
\hline Wagoner County & & & \\
\hline Coweta High School & 0.43 & 0.28 & 1.72 \\
\hline Coweta Intermediate & 0 & 0 & 0 \\
\hline Coweta Jr. High School & 0.6 & 0.2 & 1.27 \\
\hline
\end{tabular}


Appendix C- Continued

\begin{tabular}{|l|c|c|c|}
\hline Name of Schools by County & $\begin{array}{l}\text { Percentage of } \\
\text { Student Referrals }\end{array}$ & $\begin{array}{l}\text { Percentage of } \\
\text { Special Needs } \\
\text { Students referred }\end{array}$ & $\begin{array}{l}\text { Percentage of } \\
\text { special needs } \\
\text { population referred }\end{array}$ \\
\hline Okay Elementary School & 0 & 0 & 0 \\
Okay High School & 0 & 0 & 0 \\
Porter Elementary School & 0 & 0 & 0 \\
Porter High School & 0 & 0 & 0 \\
Wagoner High School & 0.15 & 0.15 & 0.63 \\
Wagoner Middle School & 0 & 0 & 0 \\
\hline
\end{tabular}

